\title{
Sensory and chemical properties of Gouda cheese
}

\author{
Y. Jo, D. M. Benoist, A. Ameerally, and M. A. Drake ${ }^{1}$ \\ Southeast Dairy Foods Research Center, Food, Bioprocessing, and Nutrition Sciences Department, North Carolina State University, \\ Raleigh 27695
}

\section{ABSTRACT}

Gouda cheese is a washed-curd cheese that is traditionally produced from bovine milk and brined before ripening for 1 to 20 mo. In response to domestic and international demand, US production of Gouda cheese has more than doubled in recent years. An understanding of the chemical and sensory properties of Gouda cheese can help manufacturers create desirable products. The objective of this study was to determine the chemical and sensory properties of Gouda cheeses. Commercial Gouda cheeses ( $\mathrm{n}=36 ; 3$ mo to $5 \mathrm{yr}$; domestic and international) were obtained in duplicate lots. Volatile compounds were extracted by solid-phase microextraction and analyzed by gas chromatographyolfactometry and gas chromatography-mass spectrometry. Composition analyses included $\mathrm{pH}$, proximate analysis, salt content, organic acid analysis by HPLC, and color. Flavor and texture properties were determined by descriptive sensory analysis. Focus groups were conducted to document US consumer perception followed by consumer acceptance testing $(\mathrm{n}=149)$ with selected cheeses. Ninety aroma-active compounds in Gouda cheeses were detected by solid-phase microextraction/gas chromatography-olfactometry. Key aroma-active volatile compounds included diacetyl, 2- and 3-methylbutanal, 2-methylpropanal, methional, ethyl butyrate, acetic acid, butyric acid, homofuraneol, $\delta$-decalactone, and 2-isobutyl-3-methoxypyrazine. Aged cheeses had higher organic acid concentrations, higher fat and salt contents, and lower moisture content than younger cheeses. Younger cheeses were characterized by milky, whey, sour aromatic, and diacetyl flavors, whereas aged cheeses were characterized by fruity, caramel, malty/nutty, and brothy flavors. International cheeses were differentiated by the presence of low intensities of cowy/barny and grassy flavors. Younger cheeses were characterized by higher intensities of smoothness and mouth coating, whereas aged cheeses were character-

\footnotetext{
Received August 5, 2017.

Accepted October 19, 2017.

${ }^{1}$ Corresponding author: mdrake@ncsu.edu
}

ized by higher intensities of fracture and firmness. American consumers used Gouda cheese in numerous applications and stated that packaging appeal, quality, and age were more important than country of origin or nutrition when purchasing Gouda cheeses. Young and medium US cheeses $\leq 6$ mo were most liked by US consumers. Three distinct consumer segments were identified with distinct preferences for cheese flavor and texture. Findings from this study establish key differences in Gouda cheese regarding age and origin and identify US consumer desires for this cheese category. Key words: Gouda cheese, flavor, preference mapping

\section{INTRODUCTION}

Gouda cheese is a washed-curd Dutch cheese that is traditionally produced from bovine milk and brined before ripening for 1 to 20 mo (van den Berg et al., 2004; Mellgren, 2005; Jung et al., 2013). Gouda and Edam cheeses constitute the 2 main types of Dutch cheese and differ internationally in their requirements for the milk fat content used to produce the cheese; partial skim milk is used for Edam cheese, and whole milk is used for Gouda cheese (Walstra et al., 1993; Codex Alimentarius, 2013). Gouda cheese is defined in the United States by the Code of Federal Regulations (CFR). The CFR specifies a maximum moisture content of $45 \%$ by weight and a minimum $46 \%$ fat content on a dry weight basis for Gouda cheeses. Between 2010 and 2014, Gouda cheese production in the United States increased from 19 to 48 million pounds per year (USDA, 2014). As a result of initiatives between US manufacturers and overseas buyers, Gouda cheese export has increased dramatically since 2008 and is considered to have the most potential for cheese export (US Dairy Export Council, 2012). Understanding the sensory and chemical properties of Gouda cheese and how they influence consumer acceptance can help manufacturers create a desirable product.

Flavor, followed by texture and appearance, are the 3 attributes that most influence liking of a food (Moskowitz and Krieger, 1995). Specific flavor profiles of products are documented using descriptive sensory 
analysis by a trained panel. Identification and characterization of key flavor compounds can be conducted using CG-olfactometry (GC-O) and GC-MS. This process has been applied to various dairy products, including sweet cream butter, berries, yogurt, milk powders, and cheeses (Wright et al., 2006; Whetstine and Drake, 2007; d'Acampora Zellner et al., 2008; Du et al., 2010). Trained panel results can be integrated to confirm GC-O profiles and to quantitatively interpret consumer acceptance (Drake, 2004). Numerous studies of dairy products have correlated analytical sensory and instrumental data or analytical sensory data and consumer acceptance (Murray and Delahunty, 2000; Young et al., 2004; Drake et al., 2008; Van Leuven et al., 2008; Childs and Drake, 2009; Shepard et al., 2013).

Previous studies with Gouda cheese have investigated fatty acid composition, the formation mechanism of lactones, and organic acid composition (Iyer et al., 1967; Califano and Bevilacqua, 2000; Alewijn et al., 2007). Sixty-three volatiles were previously identified in 2 Belgian Gouda cheeses, 1 raw-milk cheese and 1 pasteurized-milk cheese, at different ripening times by GC-MS. Characteristic flavor differences between the 2 cheeses were determined by descriptive analysis, but aroma activity was not investigated by GC-O (Van Leuven et al., 2008). Gouda cheeses previously analyzed by GC-MS were differentiated from Emmental cheeses by higher concentrations of $\delta$-decalactone and $\delta$-dodecalactone and higher intensities of "buttery" notes by sensory analyses (Dirinck and De Winne, 1999). Differences in free fatty acid (FFA) composition were documented between whole- and reduced-fat Edam cheeses (Tungjaroenchai et al., 2004). In a recent study by Inagaki et al. (2015), 16 aroma-active compounds were identified in 1 young, 1 medium, and 1 aged Gouda cheese using solvent-assisted flavor evaporation followed by aroma extract dilution analysis. Inagaki et al. (2015) showed increases of aroma-active compounds with ripening stage, but this study did not include sensory analysis and evaluated only 3 cheeses from different ripening stages.

Preference mapping is a collection of multivariate techniques used to establish relationships between instrumental and descriptive results or consumer acceptance data (Meilgaard et al., 2007). This approach has been widely applied to determine the drivers of liking of dairy products such as Cheddar cheese (Drake et al., 2008), cottage cheese (Drake et al., 2009), sour cream (Shepard et al., 2013), and Greek yogurt (Desai et al., 2013). Yates and Drake (2007) conducted a sensory study on Gouda cheese texture. Consumers preferred Gouda cheese with a smooth and cohesive texture over one with higher fracturability, firmness, or springiness.
This study suggested that flavor and texture were key drivers of liking for consumer acceptance (Yates and Drake, 2007). No previous study has investigated the chemical and sensory properties of a wide range of Gouda cheeses. The objective of this study was to characterize the sensory and chemical properties of Gouda cheese and to determine the drivers of liking for Gouda cheese with US cheese consumers. Descriptive sensory analysis and instrumental analysis were conducted on a wide array of Gouda cheeses. Subsequently, consumer focus groups and consumer acceptance testing were conducted.

\section{MATERIALS AND METHODS}

\section{Gouda Cheese}

Commercial Gouda cheeses $(\mathrm{n}=36)$ were obtained in duplicate lots from 5 countries (United States, the Netherlands, Finland, Denmark, and New Zealand; Table 1). Samples ranged in age from 3 mo to $3 \mathrm{yr}$ and included both raw- and pasteurized-milk cheeses. Samples were shipped overnight and were examined for damage upon arrival. Products were stored in the dark at $4^{\circ} \mathrm{C}$ for both descriptive analysis and consumer acceptance testing. Each cheese was subsampled for analytical instrumental analysis, stored at $-80^{\circ} \mathrm{C}$, and analyzed no later than 2 mo after arrival.

\section{Chemical Standards}

Organic acid standards, internal standards (2-methyl-3-heptanone, heptadecanoic acid, and ethyl maltol), and alkane series $\left(\mathrm{C}_{8}-\mathrm{C}_{20}\right)$ were purchased from SigmaAldrich (St. Louis, MO). Authentic standards for volatile compounds were purchased from Sigma-Aldrich and Chemstep (Martillac, France).

\section{Composition Analysis}

Proximate analysis for moisture and fat, $\mathrm{pH}$, color, and salt content measurements was conducted on all Gouda cheeses. Moisture content was determined by a modified Association of Official Analytical Chemists (AOAC) method from Bradley and Vanderwarn (2001). Briefly, $3 \mathrm{~g}$ of cheese was dried in a vacuum oven at $110^{\circ} \mathrm{C}$ for $30 \mathrm{~min}$, and the difference in mass before and after drying was measured. Fat content was determined using a modified Mojonnier extraction method (AOAC International, 2000; method 989.05) with $0.25 \mathrm{~g}$ of grated cheese. Measurements for $\mathrm{pH}$ were conducted by placing $1 \mathrm{~g}$ of grated cheese in a $45-\mathrm{mL}$ centrifuge tube (VWR International LLC, West Chester, PA) with 5 
Table 1. Moisture, fat, salt, $\mathrm{pH}$, and instrumental color values of Gouda cheeses

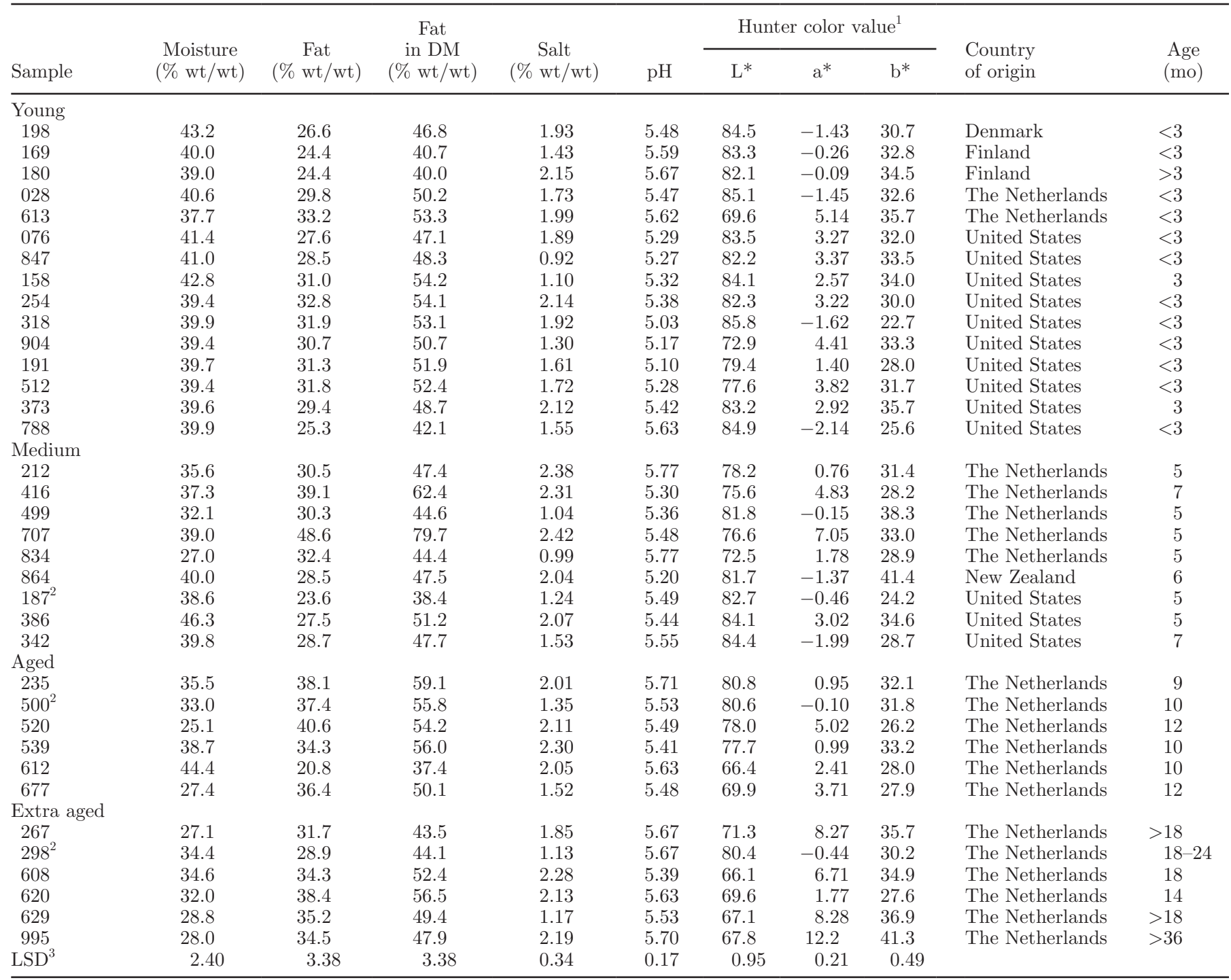

${ }^{1} \mathrm{~L}^{*}=$ lightness $\left(0=\right.$ black; $100=$ diffuse white). $\mathrm{a}^{*}=$ red/magenta (positive values) and green (negative values). $\mathrm{b}^{*}=$ yellow $($ positive values) and blue (negative values).

${ }^{2}$ Gouda cheese made with raw milk.

${ }^{3}$ Means within a column that differ by the LSD are significantly different $(P<0.05)$.

$\mathrm{mL}$ of water and vortexing the mixture for $15 \mathrm{~s}$. The $\mathrm{pH}$ was measured with a pH meter (Mettler-Toledo GmbH, Schwerzenbach, Switzerland) by inserting the $\mathrm{pH}$ electrode probe (BNC; Corning Inc., Corning, NY) into the mixture (Upreti et al., 2004). Hunter L*a*b* color analysis was performed by placing a Minolta chroma meter (CR-410; Minolta, Ramsey, NJ) directly on a $6 \times 6 \times 3 \mathrm{~cm}$ block of cheese at $23^{\circ} \mathrm{C}$ (Dufosse and De Echanove, 2005). Salt content was determined by adding $3 \mathrm{~g}$ of grated homogenized cheese to a $10-\mathrm{mL}$ beaker and analyzed by a salt analyzer (TOA-DKK SAT 500; Analyticon Instruments Corp., Springfield, NJ). All analyses were conducted in duplicate.

\section{Organic Acid Analysis}

Organic acids were extracted and analyzed by HPLC according to a modified method described by Califano and Bevilacqua (2000). Five grams of grated cheese was added to $20 \mathrm{~mL}$ of $0.013 N$ sulfuric acid (2.0N; Mallinckrodt Baker Inc., Phillipsburg, NJ) in a 120-mL centrifuge tube. Samples were shaken on high for $30 \mathrm{~min}$ (Barnstead Thermolyne 50800 Rotomix, Barnstead Thermolyne Corporation, Ramsey, MN) and centrifuged (Sorvall model RC-B5; Thermo Scientific, Waltham, MA) at $6,000 \times g$ for $10 \mathrm{~min}$. The supernatant was then collected and filtered through a $0.45-\mu \mathrm{m}$ 
nylon membrane (VWR International LLC). A $10-\mu \mathrm{L}$ injection volume was introduced to the HPLC equipped with a manual $10-\mu \mathrm{L}$ loop injector, photodiode array detector (2996; Waters Inc., Milford, MA), pump (515; Waters Inc.), inline degasser AF (Waters Inc.), and insulated column oven. Samples were analyzed by a cation exchange column (Aminex HPX-87H, $300 \times 7.8$ $\mathrm{mm}$; Bio-Rad Laboratories, Hercules, CA). The mobile phase used was $0.013 \mathrm{~N} \mathrm{H}_{2} \mathrm{SO}_{4}$, and the flow rate was $0.8 \mathrm{~mL} / \mathrm{min}$. Separated organic acids were detected at wavelengths 210 and $290 \mathrm{~nm}$ using the software Empower (Waters Inc.). Organic acids were identified by comparing retention times of chemical standards and quantified by 5 -point standard calibration curves for each organic acid. All analyses were conducted in duplicate.

\section{Headspace Solid-Phase Microextraction of Volatile Compounds}

$\boldsymbol{G C}$ - $\boldsymbol{M S}$. Volatile compounds were extracted by headspace solid-phase microextraction (SPME) and subsequently separated and identified by GC-MS using a modified method of Wright et al. (2006). Each cheese was evaluated in scan mode followed by selective ion monitoring mode. Three grams of grated Gouda cheese along with $0.23 \mathrm{~g}$ of sodium chloride was added to a 2-mL autosampler vial containing a Teflon silicon septa face (Microliter Analytical Supplies, Suwannee, GA). An internal standard (2-methyl-3-heptanone in ethyl ether at $81 \mathrm{mg} / \mathrm{kg}$ ) was added to the samples. All samples were injected using a 3-phase SPME fiber (divinylbenzene/carboxen/polydimethylsiloxane; Supelco, Bellefonte, PA) using a CTC Analytics Combi PAL autosampler (Leap Technologies, Carrboro, NC) attached to an Agilent 7820A GC and 5975 MSD (Agilent Technologies Inc., Santa Clara, CA). Compounds were separated on a ZB-5ms column (30 m length $\times$ $0.25 \mathrm{~mm}$ i.d. $\times 0.25 \mu \mathrm{m}$ film thickness; Phenomenex, Torrance, CA). The GC method was an initial temperature of $40^{\circ} \mathrm{C}$ for $3 \mathrm{~min}$ before increasing at a rate of $10^{\circ} \mathrm{C} / \mathrm{min}$ to $90^{\circ} \mathrm{C}$. The rate was then increased by $5^{\circ} \mathrm{C} / \mathrm{min}$ to $200^{\circ} \mathrm{C}$ and $20^{\circ} \mathrm{C} / \mathrm{min}$ to $250^{\circ} \mathrm{C}$ and held for 5 min. The SPME fiber was introduced into the split/ splitless injector at $250^{\circ} \mathrm{C}$ at a pressure of $48.7 \mathrm{kPa}$, and a $1 \mathrm{~mL} / \mathrm{min}$ of constant flow rate of helium was maintained. The purge time was set at $1 \mathrm{~min}$. The MS transfer line was held at $250^{\circ} \mathrm{C}$, with the quad at $150^{\circ} \mathrm{C}$ and the source at $230^{\circ} \mathrm{C}$. All volatile compounds were identified using the National Institute of Standards and Technology (NIST, 2014) mass spectral database, authentic standards injection, and retention indices calculation (van den Dool and Kratz, 1963) using an alkane series.

$\boldsymbol{G C}$ - $\boldsymbol{O}$. Aroma-active compounds in Gouda cheeses were characterized by GC-O. All injections were made on an Agilent 6850 GC-flame ionization detector (FID) attached with an olfactometer port (Agilent Technologies Inc.). Sample introduction was accomplished using a manual SPME holder equipped with a DVB/CAR/ PDMS fiber (Supelco). Five grams of grated cheese was added to a 40-mL amber screw-top vial (Supelco) along with $17 \%$ (wt/wt) sodium chloride. Vials were equilibrated for $25 \mathrm{~min}$ at $40^{\circ} \mathrm{C}$ using a Reacti Therm TS-18821 heating/stirring module (Thermo Scientific). The SPME fiber was exposed to the samples for 30 min at a depth of $20 \mathrm{~mm}$. The fiber was retracted and injected at $30 \mathrm{~mm}$ in the $\mathrm{GC}$ inlet for $5 \mathrm{~min}$. The GC oven was initially held at $40^{\circ} \mathrm{C}$ for 3 min with a ramp rate of $10^{\circ} \mathrm{C} / \mathrm{min}$ to $150^{\circ} \mathrm{C}$, and then was increased at a rate of $30^{\circ} \mathrm{C} / \mathrm{min}$ to $200^{\circ} \mathrm{C}$ and maintained for $5 \mathrm{~min}$. Effluent was split 1:1 between the FID and sniffing port using deactivated fused-silica capillaries (1 m length $\times 0.25 \mathrm{~mm}$ i.d.; Phenomenex). The FID sniffing port was held at a temperature of $300^{\circ} \mathrm{C}$, and the port was supplied with humidified air at $30 \mathrm{~mL} / \mathrm{min}$. Cheeses were evaluated in duplicate by 2 highly trained sniffers (each with $>50 \mathrm{~h}$ of previous experience with GC-O) on both ZB-5 and ZB-Wax columns (30 m length $\times 0.25$ $\mathrm{mm}$ i.d. $\times 0.25 \mu \mathrm{m}$ film thickness; Phenomenex). Each sniffer recorded retention time, aroma character, and perceived intensity. Aroma-active compounds detected by GC-O and GC-MS were matched by retention indices values, mass spectra, and odor properties with those of authentic standards under identical conditions.

Compound Quantification. Selected aroma-active compounds were chosen for quantification based on detection frequency in cheeses, odor properties, and evaluation of the previous literature (Arora et al., 1995; Preininger et al., 1996; Milo and Reineccius, 1997; Suriyaphan et al., 2001; Curioni and Bosset, 2002; Avsar et al., 2004; Van Leuven et al., 2008). Selected compounds were quantified using 5-point standard addition curves with internal standard calibration (minimum $\mathrm{R}^{2}>$ 0.92). The area of compounds originally present in the cheeses served as a baseline before the addition of known compound concentrations. Response factors (the area response from the GC-MS of a known concentration) relative to the internal standard of these compounds were obtained and plotted to build a standard curve for each individual compound. The concentrations of the selected compounds in the cheeses were then quantified using the area ratio of compound to the internal standard. 
Furaneol, sotolone, and homofuraneol were quantified using a method adapted from Carunchia Whetstine et al. (2005) with modifications from Frank et al. (2004) and Du et al. (2010). A method adapted from Drake et al. (2010) was applied for other compounds. Eighty microliters of $300 \mathrm{mg} / \mathrm{kg}$ ethyl maltol in ethanol was used as an internal standard for furanone standard addition curves, and $20 \mu \mathrm{L}$ of $81 \mathrm{mg} / \mathrm{kg}$ 2-methyl-3-heptanone in ethyl ether was used as the internal standard for all other standard addition curves. A 3-phase SPME fiber (DVB/CAR/PDMS; Supelco) was used to extract compounds. All compounds were quantified using an Agilent 7820A GC and 5975 MSD equipped with a ZB-5ms column $(30 \mathrm{~m} \times 0.25 \mathrm{~mm} \times 0.25 \mu \mathrm{m}$; Phenomenex $)$.

\section{Sensory Analysis}

Descriptive Analysis. Sensory testing was performed in compliance with the North Carolina State University Institutional Review Board for Human Subjects approval. All cheeses were evaluated at $15^{\circ} \mathrm{C}$. Panelists expectorated samples and were provided with room temperature deionized water and unsalted crackers for palate cleansing.

For flavor evaluation, a trained descriptive sensory panel $(\mathrm{n}=8 ; 6$ females and 2 males, ages $23-50 \mathrm{yr})$ evaluated the cheeses in triplicate using an established cheese flavor lexicon (Drake, 2007; Drake et al., 2001, 2005) and a 0- to 15-point universal intensity scale consistent with the Spectrum method (Meilgaard et al., 2007). Each panelist had at least $150 \mathrm{~h}$ of prior experience with descriptive analysis of flavor with various dairy products, including cheese and yogurt. Gouda cheeses were cut into $3 \times 3 \mathrm{~cm}$ cubes, and 4 cubes were placed into lidded 60 -mL soufflé cups with 3 -digit codes. Four cheeses were evaluated in sessions, with an enforced 2-min rest between samples. Replications were evaluated on different days. Compusense Cloud (Compusense, Guelph, ON, Canada) was used for data collection.

For texture evaluation, a trained descriptive sensory panel ( $\mathrm{n}=10 ; 10$ females, ages $35-55 \mathrm{yr}$ ) evaluated the cheeses in triplicate using a 0 - to 15-point product-specific (visual and texture) scale (Brown et al., 2003). Each panelist had approximately $100 \mathrm{~h}$ of prior experience with descriptive analysis of texture of dairy products, including cheese. Cheeses were cut into $1 \times 1 \mathrm{~cm}$ cubes, and 16 cubes were placed into lidded 120-mL soufflé cups with 3 -digit codes. Data were collected using Compusense Cloud. Results from descriptive analysis of flavor and texture were used to select representative cheeses for consumer acceptance testing.

Focus Groups. Three 1.5-h focus groups $(\mathrm{n}=28)$ were conducted to qualitatively characterize consumer perception of Gouda cheese. Gouda cheese consumers were recruited from an online database of 8,000 individuals maintained by the Sensory Service Center (North Carolina State University, Raleigh). Panelists were primary shoppers with household income $>\$ 40,000$ who self-reported purchase of Gouda cheese at least twice a month and consumed cheese weekly. Focus groups were moderated by a trained guide who asked participants a series of predetermined questions in a roundtable format (Figure 1). Focus groups were also video recorded. Consumers were asked questions regarding unique qualities, usage, flavor preferences, and purchase habits toward Gouda cheese. Key points based on frequency of responses from focus groups were used in creating the ballot for quantitative consumer acceptance testing.

Consumer Acceptance Test. Consumer acceptance testing was conducted to determine consumer preferences for flavor and texture of Gouda cheeses. Ten representative Gouda cheeses were selected based on examination of principal components biplots, product mean attributes, and market share. Testing was conducted in accordance with the North Carolina State University Institutional Review Board for the Protection of Human Subjects in Research regulations. Consumer acceptance testing was performed over $2 \mathrm{~d}$, with each consumer evaluating a randomized partial presentation of 5 cheeses per day. Self-reported Gouda cheese consumers $(\mathrm{n}=149)$ were recruited using a survey launched into an online database of 8,000 individuals maintained by North Carolina State University. All consumers were primary shoppers with an annual household income $>\$ 40,000$ who purchased Gouda cheese at least twice a month and consumed cheese weekly. Panelists were compensated with a $\$ 35$ gift card to a local store upon completion of the 2-d test. Compusense Cloud (Compusense) was used for data collection.

Gouda cheeses were cut into $3 \times 3 \mathrm{~cm}$ cubes and placed into lidded $60-\mathrm{mL}$ soufflé cups with lids with random 3-digit blinding codes. Cheeses were served at $8^{\circ} \mathrm{C}$. Each day samples were presented monadically using a Williams design serving order. Panelists were first asked to evaluate aroma, appearance, and color liking for each cheese using a 9-point hedonic scale. After consuming several bites, panelists evaluated each sample for flavor, saltiness, texture, and creaminess liking using a 9-point hedonic scale. Panelists used a 5-point anchored just-about-right (JAR) scale to evaluate flavor intensity, salty taste intensity, texture, and creaminess attributes. For each sample, panelists were also asked purchase intent and usage questions. Consumers were provided with spring water and unsalted crackers for palate cleansing, and a 3-min delay was enforced between samples. 


\section{Moderator guide for Gouda cheese}

Respondent introductions: Introduce yourself and share your favorite variety of cheese

Focus Area 1: Perception and use of Gouda cheese

- Why do you buy Gouda cheese (G)? What is unique about this cheese variety that keeps you buying it?

- Where do you find $\mathrm{G}$ in your grocery store and what form do you buy it in?

- Who in your household (hh) consumes it and how often do you/your hh consume it?

- In what ways do you use $\mathrm{G}$ and what makes it suitable for this use?

- Discuss the meaning of each of the following terms and if they are important to your $\mathrm{G}$ usage: Ingredient quality, Specialty product, Labels, Nutritional value, Country of origin, Artisanal produced, Raw milk G, Pasteurized milk G, milk source (i.e. cow versus sheep milk G)

Focus Area 2: The ideal Gouda cheese

- Describe the ideal $\mathrm{G}$ in terms of appearance, shape and color (show pictures and have panelist describe likes/dislikes)

- Describe the ideal $\mathrm{G}$ in terms of texture. What other varieties of cheese have a similar texture?

- What other factors influence your decision to purchase G?

- Do you tend to stick with $\mathrm{G}$ you have tried and liked or try new ones?

Focus Area 3: Gouda cheese purchasing

- Where do you prefer to go to purchase $\mathrm{G}$ and why?

- Describe your typical G buying experience: who is with you, are there any other considerations not previously mentioned before making a $\mathrm{G}$ purchase?

- Are there any must haves for purchasing a G? Any absolute nos?

Wrap up: Inquire as to any final thoughts and summarize the major findings

Figure 1. Focus group discussion guide. 


\section{Statistical Analysis}

Statistical analysis was conducted using XLSTAT software (version 2016; Addinsoft, New York, NY). Compositional results, volatile compound concentrations, descriptive analysis results, and consumers liking scores were analyzed by ANOVA with Fisher's least significant difference test at a significance level of $P$ $<0.05$. Principal component analysis was applied to descriptive analysis to determine how products were differentiated relative to one another. Consumer JAR scores were evaluated by chi-squared analysis, and purchase intent was evaluated using a Kruskal-Wallis test with Dunn's post hoc test. For consumer segmentation, hierarchical agglomerative clustering and k-means analysis were used to determine the number of clusters. Clusters were validated using discriminant analysis. Partial least squares analysis was then conducted on descriptive means and consumer data to identify drivers of liking and disliking for each cluster.

\section{RESULTS AND DISCUSSION}

\section{Composition Analysis}

All cheeses met the moisture requirements for CFR of $<45 \%$ (Table 1). Several blocks of Gouda-style cheeses $(169,180,499,834,187,788,612,267$, and 298) did not meet CFR regulations for Gouda fat content $(>46 \%$ dry weight). As expected, Gouda cheeses ripened for longer periods were likely to be lower in moisture and had higher fat and salt contents than younger cheeses. Fat and moisture contents were within the range of previous composition analysis of Gouda cheeses by Jung et al. (2013) and Welthagen and Viljoen (1998). Cheeses aged more than 3 mo were darker in color and more yellow in color than younger cheeses, as indicated by lower $L^{*}$ values and higher $b^{*}$ values (Table 1 ). Color differences between younger and aged Gouda cheeses were likely a result of increased melanoidins responsible for brown pigmentation (Fox et al., 2000). Melanoidin formation is a nonenzymatic browning reaction that occurs in cheese and dairy products when galactose produced from lactose hydrolysis reacts with AA produced from proteolytic breakdown (Corzo et al., 2000). Another possible explanation for this color difference between the more aged cheeses and the younger cheeses could be a loss of moisture from the ripening process. Kumar et al. (2006) suggested that the contraction of the protein matrix with loss of water could affect color. Color results were consistent with results for Egyptian Gouda cheeses reported by El-Nimr et al. (2010). All $\mathrm{pH}$ values for cheeses were within the $\mathrm{pH}$ range of 4.9 to 5.6 for Gouda cheeses stated by van den Berg et al. (2004), and the average $\mathrm{pH}$ value was 5.49.

\section{Organic Acid Analysis}

Six organic acids were quantified in Gouda cheeses (Table 2). Lactic acid was present at the highest concentration for all cheeses $(P<0.05)$. Overall, organic acid concentrations increased with ripening time. These results were also consistent with organic acid determination of Gouda cheeses by Califano and Bevilacqua (2000) and Skeie et al. (2001). Organic acids are influential to flavor and aroma compound production; lactic acid is important to quality, manufacturing, and ripening in cheese (Califano and Bevilacqua, 2000). Production of lactic, citric, acetic, and pyruvic acids in Gouda cheese is directly correlated with time and temperature (Califano and Bevilacqua, 2000). Lactic acid contributes to the early stages of cheese maturation and may undergo transformation by numerous other pathways to form other flavor compounds (McSweeney and Sousa, 2000). Although a minor reaction in the flavor of cheese, oxidation of lactic acid to acetic acid and carbon dioxide by nonstarter lactic acid bacteria is one possible reaction; acetic acid has been shown to contribute to the flavor of Cheddar and Dutchtype cheeses (McSweeney and Sousa, 2000; Singh et al., 2003). Citrate metabolism starters (Cit+) utilize citrate as an energy source; citrate is often co-metabolized with other sugars such as lactose (Dimos et al., 1996). Citrate metabolism and the resulting $\mathrm{CO}_{2}$ affect the texture of the Gouda and lead to the "eye" formation present in some Gouda cheese (Dimos et al., 1996; McSweeney and Sousa, 2000). Although the majority of citric acid native to raw milk is lost to whey, retained citric acid may be further metabolized into a variety of flavor components, primarily acetic acid, 2,3-butanedione (diacetyl), and acetoin (McSweeney and Sousa, 2000).

\section{Volatile Compound Analysis}

Ninety aroma-active compounds were detected in cheeses by head space-SPME-GC-O, including 6 FFA, 7 sulfur-derived compounds, 20 aldehydes, 10 esters, 9 nitrogen-derived compounds, 3 lactones, 3 alkanes, 11 alcohols, 13 ketones, 3 furanones, and 5 unknowns (Tables 3 and 4). The following compounds were reported for the first time as odor active in Gouda cheese by GC-O and were present in at least 30 of 36 cheeses: diacetyl, acetic acid, 2-methylbutanal, and methional. Acetic acid and methional were previously identified as significant to Gouda cheese flavor based on aroma 
extract dilution analysis of solvent extracts from 3 cheeses by Inagaki et al. (2015). 2-Methylpropanal was detected by GC-O for the first time in at least 10 of 14 aged (>9 mo) Gouda cheeses. Butyric acid, 2-isopropyl3 -methoxypyrazine, and sotolone were also present in the Gouda cheeses and were previously reported as potent odorants by Inagaki et al. (2015). Aroma-active compounds that were identified above in Gouda cheeses have been previously detected in Emmental, Cheddar, blue, and hard Italian cheeses by GC-O (Pillonel et al., 2003; Avsar et al., 2004; Frank et al., 2004).

Twenty-five compounds were quantified using GCMS, including 4 FFA, 4 sulfur-derived compounds, 6 aldehydes, 3 esters, 1 pyrazine, 1 lactone, 3 furanones, diacetyl, acetoin, and 2-acetyl-1-pyrroline (Tables 5 and 6). Twelve of the compounds quantified were detected in all cheeses by GC-MS. These compounds include acetic acid, butyric acid, hexanoic acid, dimethyl sulfide, dimethyl trisulfide, methional, hexanal, heptanal, diacetyl, ethyl butyrate, and 2- and 3-methylbutanal. All compounds except sotolone, homofuraneol, and isobutyl acetate were previously quantified in Gouda cheeses (Van Leuven et al., 2008; Jung et al., 2013; Inagaki et al., 2015). Aged cheeses were higher in concentrations of 2- and 3-methylbutanal, butyric acid, 2-isobutyl-3-methoxypyrazine, $\delta$-decalactone, and homofuraneol. As expected, higher concentrations of $\delta$-decalactone, furaneol, sotolone, and homofuraneol were detected from cheeses with higher fat contents and longer age time and those made from raw milk. These compounds are produced from the conversion of peptides/AA or milk fats by enzymes from the lactic

Table 2. Organic acid concentrations $(\mathrm{mg} / \mathrm{kg})$ of Gouda cheeses

\begin{tabular}{|c|c|c|c|c|c|c|}
\hline Sample & Lactic & Citric & Acetic & Pyruvic & Propionic & Butyric \\
\hline \multicolumn{7}{|l|}{ Young } \\
\hline 198 & 3.733 & 59.3 & 111 & 4.89 & 81.8 & 8.72 \\
\hline 169 & 3,049 & 27.3 & 111 & 20.0 & 106 & 61.1 \\
\hline 180 & 3,203 & 42.2 & 152 & 30.0 & 74.8 & 3.14 \\
\hline 028 & 3,336 & 56.4 & 123 & 15.7 & 136 & 5.86 \\
\hline 613 & 3,616 & 56.4 & 151 & 18.8 & 134 & 14.7 \\
\hline 076 & 3,121 & 58.0 & 101 & 9.28 & 77.4 & 4.49 \\
\hline 847 & 2,968 & 82.9 & 83.1 & $\mathrm{ND}^{1}$ & 145 & 3.68 \\
\hline 158 & 2,384 & 75.7 & 62.6 & ND & 106 & 5.81 \\
\hline 254 & 3,416 & ND & 122 & 13.2 & 240 & 7.83 \\
\hline 318 & 3,933 & 123 & 73.9 & 33.4 & 112 & 4.27 \\
\hline 904 & 3,436 & ND & 147 & 23.9 & 347 & 14.0 \\
\hline 191 & 3,699 & 123 & 110 & 28.7 & 230 & 9.14 \\
\hline 512 & 3,430 & ND & 135 & 18.6 & 294 & 10.9 \\
\hline 373 & 2,595 & 209 & ND & 22.6 & 240 & 9.46 \\
\hline 788 & 2,762 & 130 & ND & 26.4 & 433 & 95.2 \\
\hline \multicolumn{7}{|c|}{ Medium } \\
\hline 212 & 3,645 & ND & 162 & 43.6 & 291 & 18.9 \\
\hline 416 & 3,576 & ND & 124 & 22.9 & 154 & 19.1 \\
\hline 499 & 3,460 & 19.6 & 105 & 4.78 & 72.1 & 50.0 \\
\hline 707 & 2,862 & 37.9 & 71.9 & 17.3 & 74.2 & 9.19 \\
\hline 834 & 5,376 & ND & 191 & 52.2 & 300 & 30.0 \\
\hline 864 & 3,560 & 259 & ND & 28.3 & 158 & 9.88 \\
\hline 187 & 3,071 & ND & 122 & 13.1 & 230 & 21.3 \\
\hline 386 & 3,060 & 267 & 121 & 13.5 & 198 & 85.0 \\
\hline 342 & 3,008 & 57.9 & 130 & 44.7 & 426 & 53.6 \\
\hline \multicolumn{7}{|l|}{ Aged } \\
\hline 235 & 4,343 & ND & 186 & 53.0 & 355 & 61.8 \\
\hline 500 & 3,335 & ND & 134 & 26.2 & 382 & 97.7 \\
\hline 520 & 3,124 & 193 & 27.4 & 32.2 & 92.9 & 57.5 \\
\hline 539 & 4,013 & ND & 204 & 33.4 & 145 & 23.3 \\
\hline 612 & 5,446 & 185 & 190 & 18.8 & 233 & 40.5 \\
\hline 677 & 4,717 & ND & 170 & 49.9 & 475 & 1,123 \\
\hline \multicolumn{7}{|c|}{ Extra aged } \\
\hline 267 & 3,842 & 71.3 & 282 & 20.7 & 316 & 1,402 \\
\hline 298 & 3,126 & ND & 118 & 19.8 & 316 & 96.4 \\
\hline 608 & 1,150 & ND & 43.5 & ND & 38.2 & 82.8 \\
\hline 620 & 4,969 & 160 & 188 & 53.2 & 217 & 30.4 \\
\hline 629 & 5,033 & ND & 173 & 31.2 & 249 & 13.7 \\
\hline 995 & 5,379 & ND & 499 & 37.7 & 419 & 602 \\
\hline $\mathrm{LSD}^{2}$ & 29.8 & 22.3 & 18.5 & 3.95 & 18.3 & 22.3 \\
\hline
\end{tabular}

${ }^{1} \mathrm{ND}=$ not detected

${ }^{2}$ Means within a column that differ by the LSD are significantly different $(P<0.05)$. 
acid bacteria in the cheese (El Soda, 1993). Proteolytic and lipolytic activity of lactic acid bacteria appears to yield these flavor compounds during ripening (Olson, 1990; El Soda, 1993). Moreover, raw milk contains an indigenous lipase and esterase, which contributes to extensive lipolysis and subsequent flavors during ripening (McSweeney and Sousa, 2000).

The concentration of volatile compounds derived from milk fat changes with aging time of Gouda cheese. Milk fat is crucial to characteristic cheese flavor because it undergoes various reactions such as hydrolysis, oxidation, and esterification and produces FFA, lactones, esters, and ketones that contribute to the overall flavor of cheese (McSweeney and Sousa, 2000; Alewijn et al., 2005). In cheese, hydrolysis of triglycerides in milk fat is more influential to cheese flavor than oxidation because of the negative oxidation-reduction potential of cheese (McSweeney and Sousa, 2000). Short-chain fatty acids (C4-C8) have an important role in cheese flavor due to their characteristic flavors (Urbach, 1997; Collins et al., 2003; Cadwallader and Singh, 2009) and being precursors of flavor compounds such as lactones, aldehydes, and alcohols (McSweeney and Sousa, 2000). Considering the similar FFA composition of Cheddar and Gouda cheeses (Urbach, 1997), and consistent with previous studies of Cheddar cheese (Milo and Reineccius, 1997; Drake et al., 2010), butyric acid was likely to have the highest aroma impact of the fatty acids in aged Gouda cheeses. As seen in Tables 5 and 6, increases of butyric acid in aged cheese could be either from lipase selectivity and preference for the formation of short-chain FFA or attributed and synthesized by microflora in cheese (McSweeney and Sousa, 2000; Alewijn et al., 2005). Aldehydes derived from autoxidation of UFA in milk fat were also distinct between young and aged Gouda cheeses. Increased concentrations of hexanal, heptanal, and octanal were observed in aged and higher fat Gouda cheeses. These aldehydes can impart green, hay, and stale flavors in cheese (Van Leuven et al., 2008).

Lactones are formed by the nonenzymatic transesterification of hydroxy fatty acids (Alewijn et al., 2007). Both $\delta$ - and $\gamma$-isomers impart delicate, sweet, coconutlike flavors in Cheddar, Gouda, Parmesan, blue-type, and other cheeses (McSweeney and Sousa, 2000; Drake et al., 2001; Alewijn et al., 2007). In this study, $\delta$-decalactone was selected for quantification due to its significant effect on cheese flavor (Milo and Reineccius, 1997; Zehentbauer and Reineccius, 2002). Consistent with Alewijn et al. (2005), $\delta$-decalactone is likely to increase in aged Gouda cheeses. Because $\delta$-lactone in cheese has been known to increase rapidly compared with $\gamma$-lactone (Urbach, 1993; Alewijn et al., 2005), a higher concentration of $\delta$-decalactone in aged Gouda cheeses would be expected. Changes in the concentration of $\delta$-decalactone during ripening are possibly associated with both ripening temperature and nonstarter lactic acid bacteria (Rehman et al., 2000; Alewijn et al., 2005). Lactone formation in Gouda cheese is most likely to originate from a nonenzymatic 1-step transesterification reactions, where hydroxy fatty acids are esterified and then release the corresponding lactones directly (Alewijn et al., 2007).

Esters are commonly found in cheese (Urbach, 1997) and are formed via esterification of an FFA with an alcohol (McSweeney and Sousa, 2000; Alewijn et al., 2005). Esters contribute fruity flavors to dairy products and are considered more desirable in cheeses such as Parmesan and Danish blue than in other varieties (Urbach, 1997; Cadwallader and Singh, 2009). As expected, ethyl butyrate was present in all Gouda cheeses because butyric acid was the predominant FFA in Gouda cheeses. In addition, the concentration of ethyl butyrate was higher in aged cheeses made with raw milk, which is consistent with a previous study (Alewijn et al., 2005). Alewijn et al. (2005) demonstrated the strong correlation between the level of ethyl esters and short-chain FFA throughout ripening, particularly with cheeses made from raw milk, possibly due to higher esterase activity in raw milk. Esterase activity of lactic acid bacteria can affect both lipolytic and ester flavors of cheese (Holland et al., 2002, 2005). Holland et al. (2005) noted that esterases of lactic acid bacteria are able to hydrolyze milk fat, producing FFA as well as synthesis of flavor-active esters via a 1-step transesterification.

Diacetyl is an important contributor to the flavor of Dutch-type cheese (McSweeney and Sousa, 2000). It contributes a buttery flavor to younger cheeses and typically is present in low concentrations by $6 \mathrm{mo}$ (Urbach, 1997; Drake et al., 2010). Diacetyl is formed from citrate metabolism along with lactate and its reduction product, including acetoin (McSweeney and Sousa, 2000), but increases of diacetyl could be related to cheese storage in the warm room (Zerfiridis et al., 1984).

Volatile compounds derived from AA and proteolysis were present at higher concentrations in longer aged cheeses. This would be expected because proteolysis is the primary reaction during cheese ripening, developing flavors through catabolism of peptides and free AA (McSweeney and Sousa, 2000). Small peptides and free $\mathrm{AA}$ are known to contribute to the background flavor of most cheese varieties (McSweeney and Sousa, 2000). In addition, they can contribute to cheese flavors as precursors of volatile compounds such as aldehydes, acids, alcohols, and sulfur compounds (Yvon 


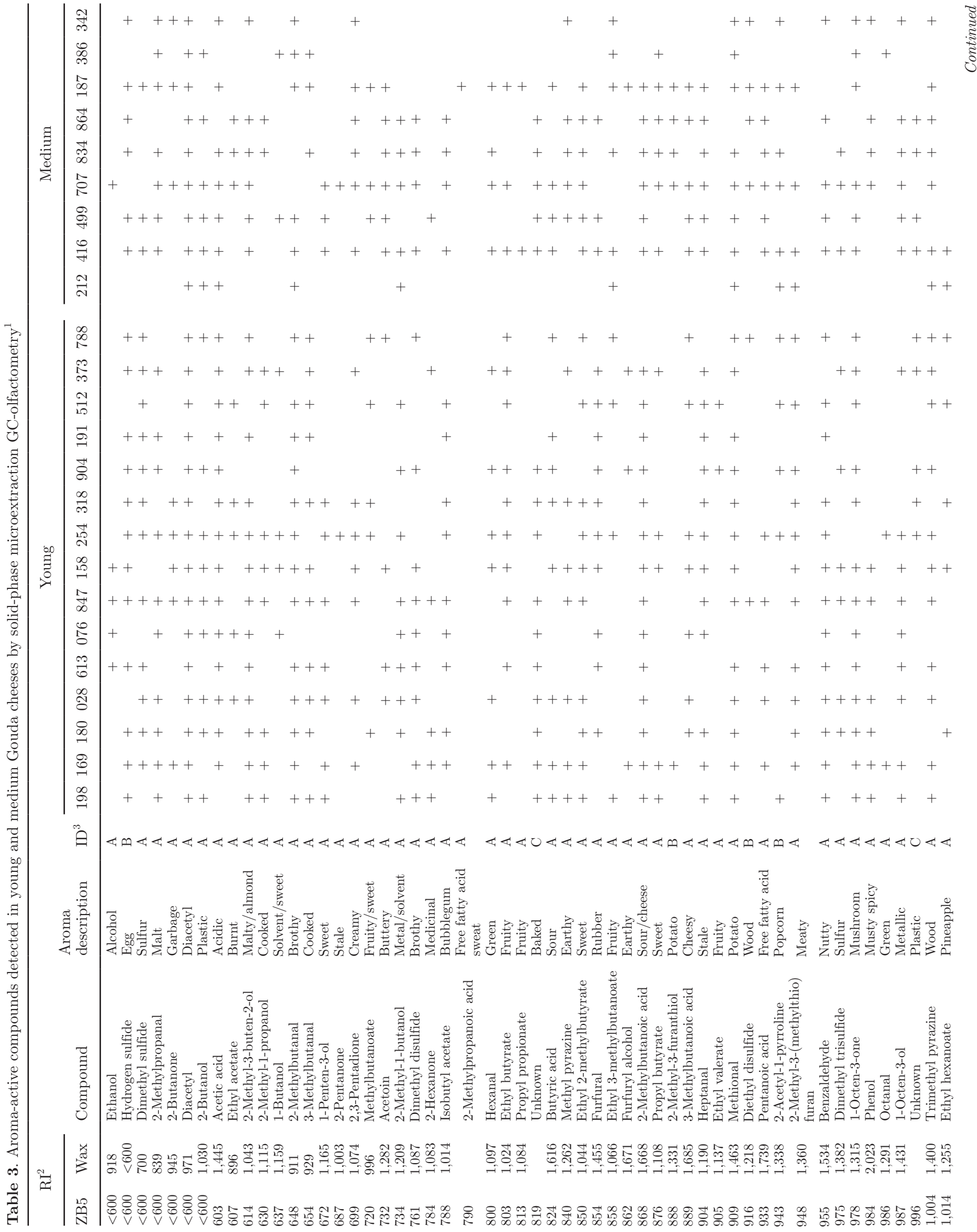




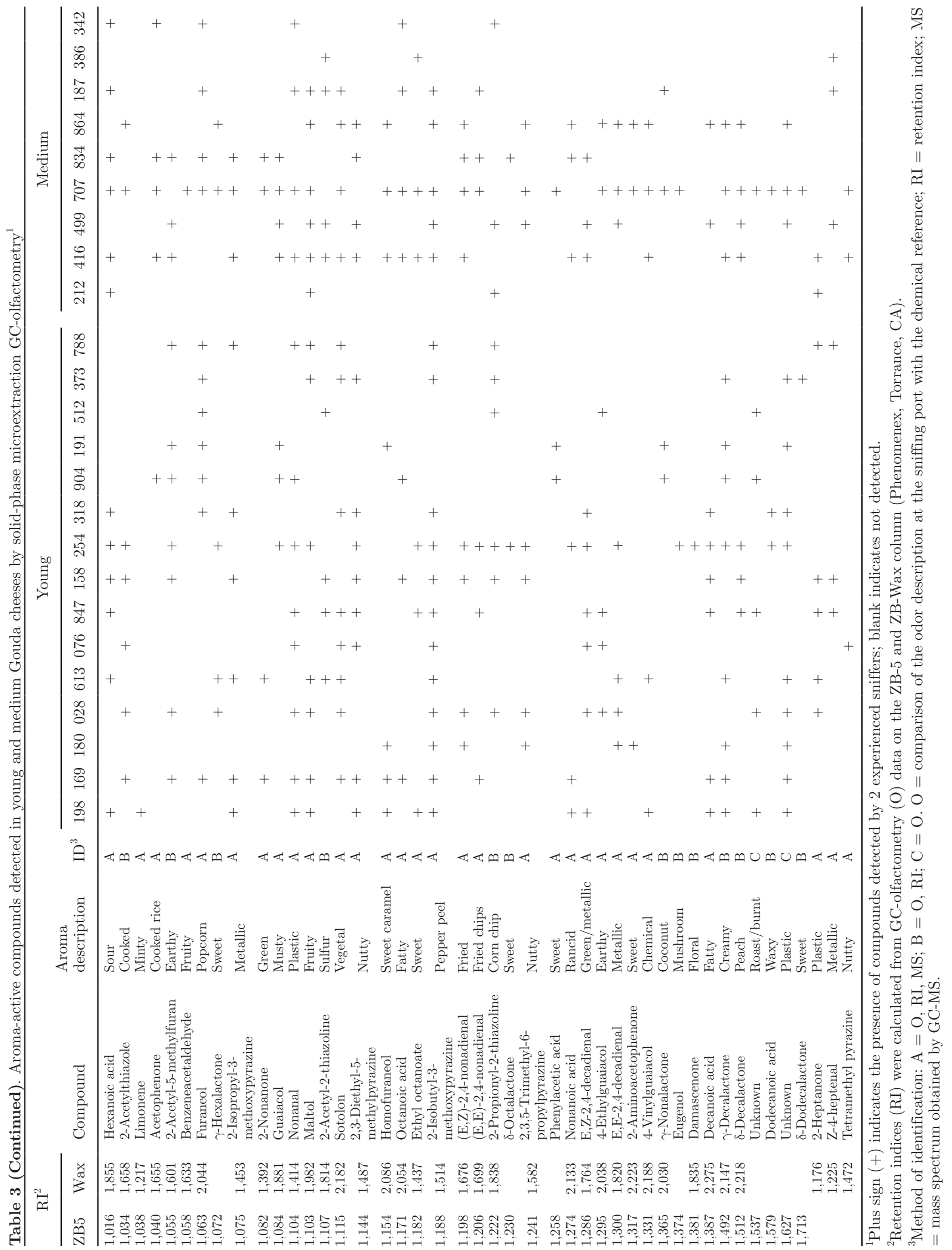




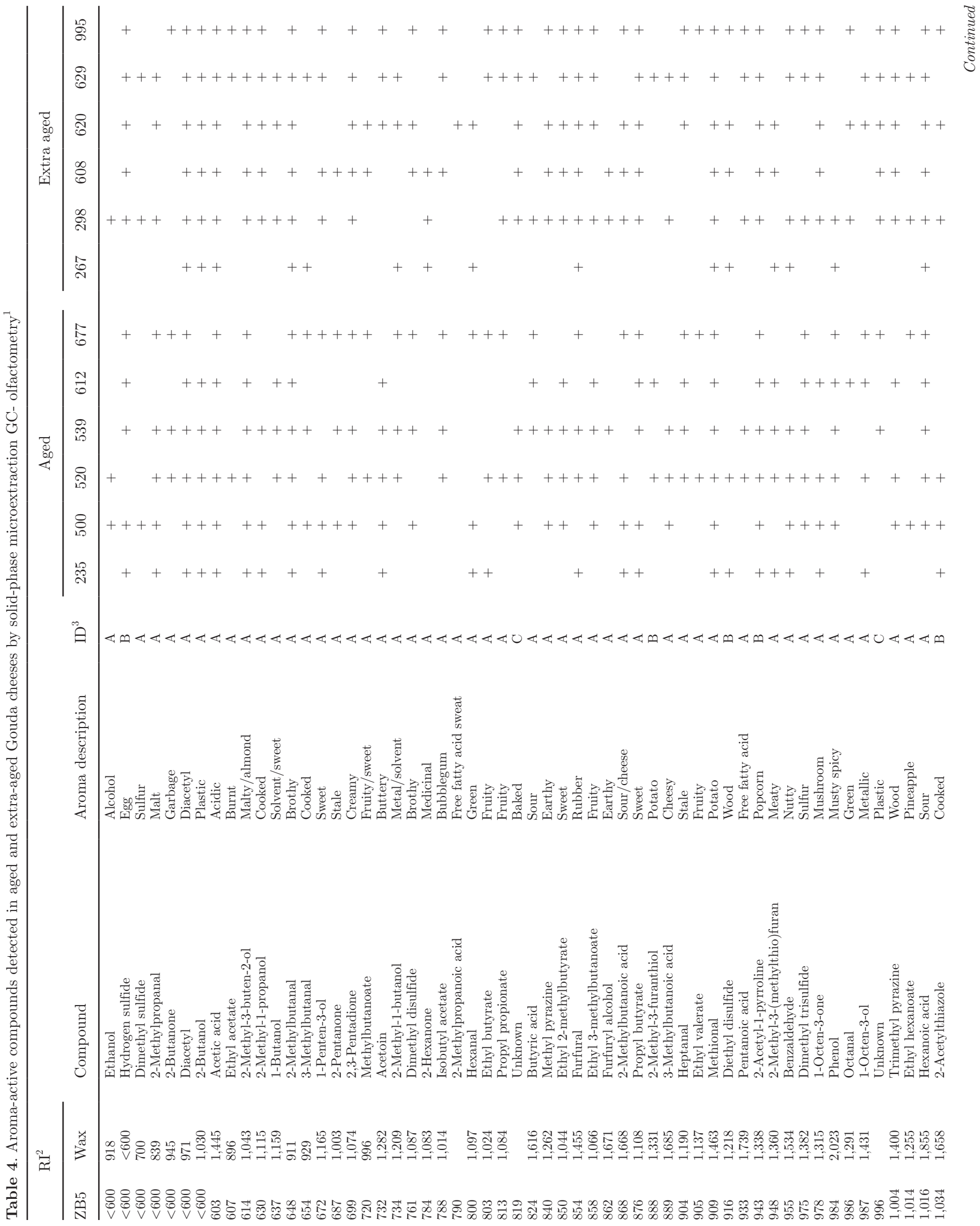




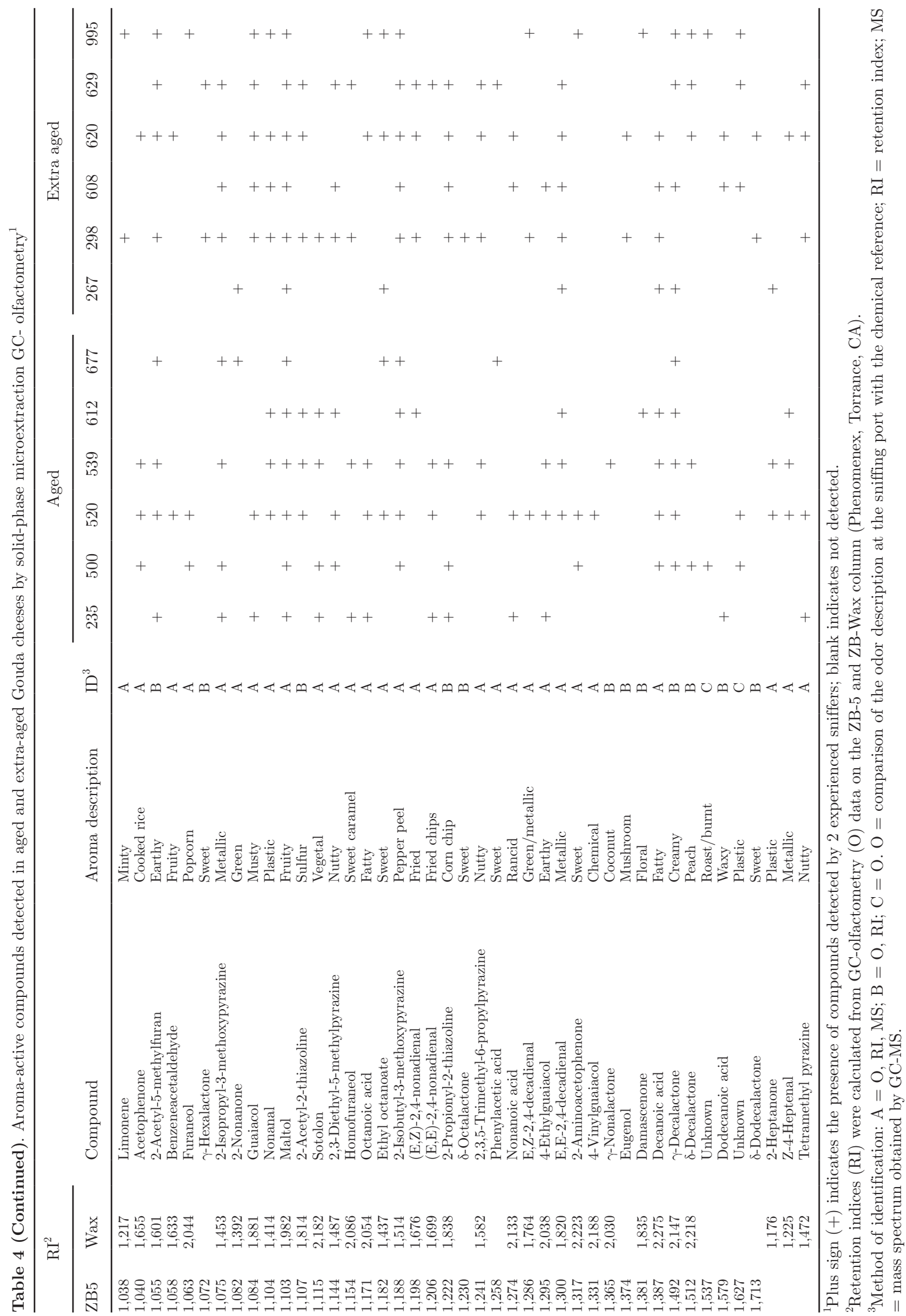




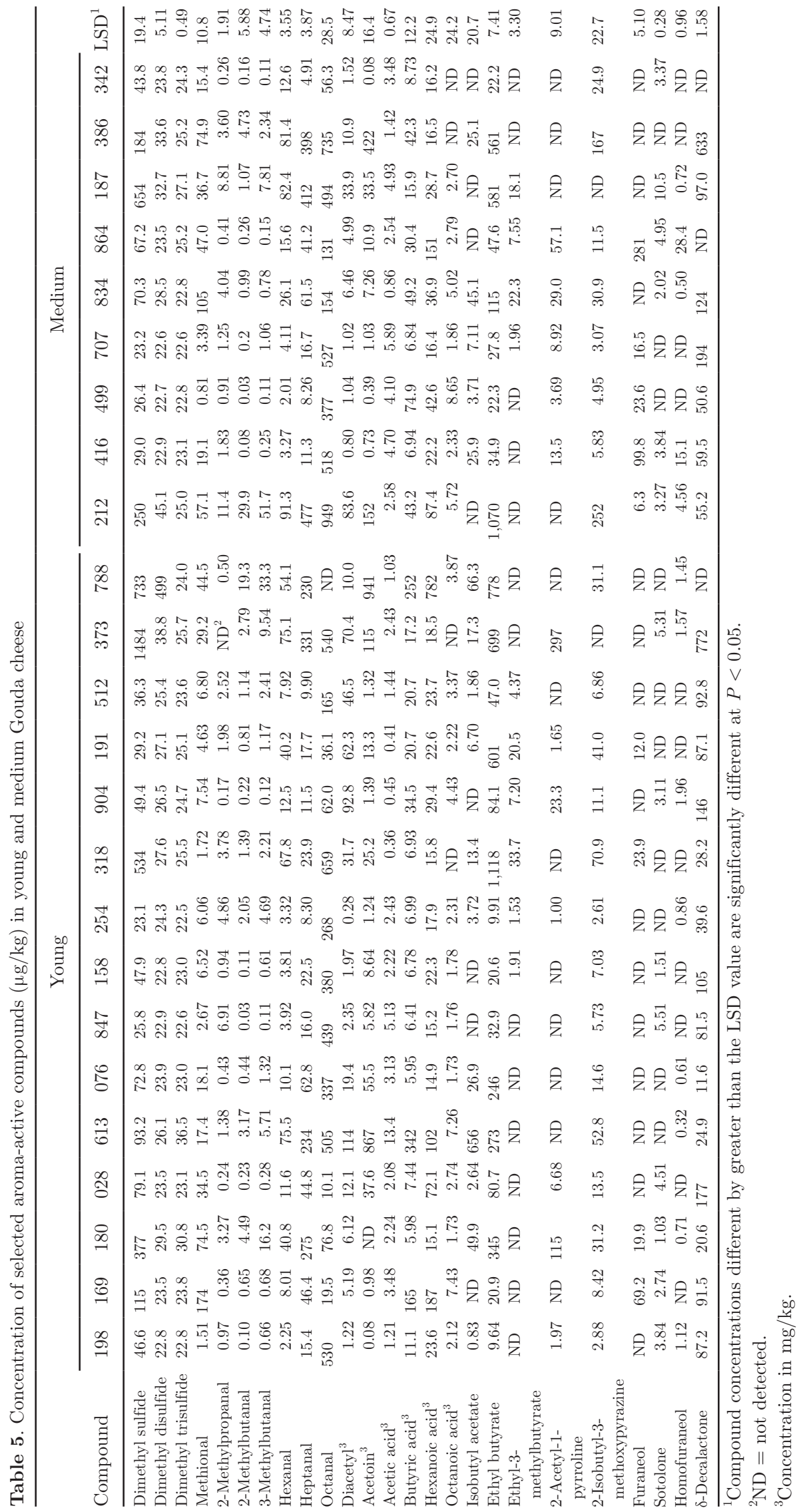


药|

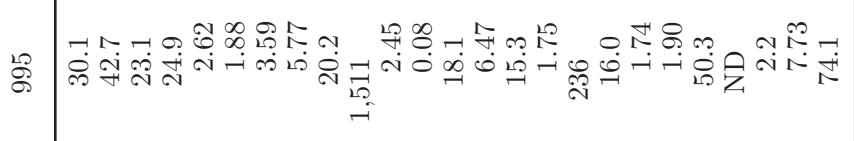

व

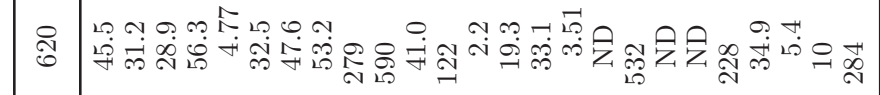

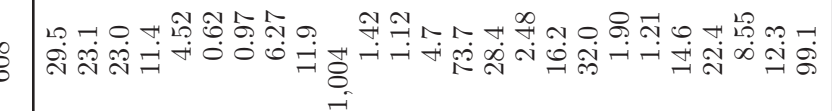

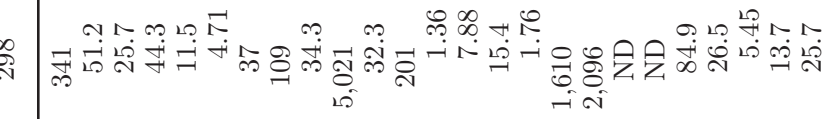

苍

点

党

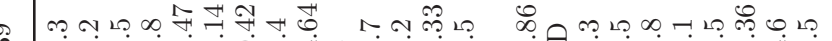
旅

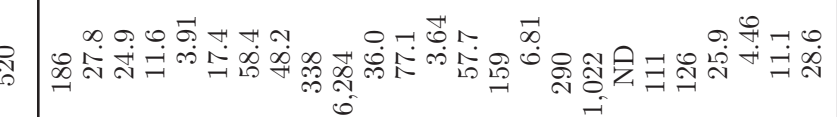

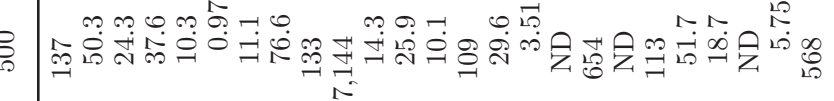

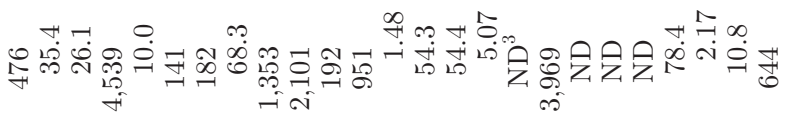

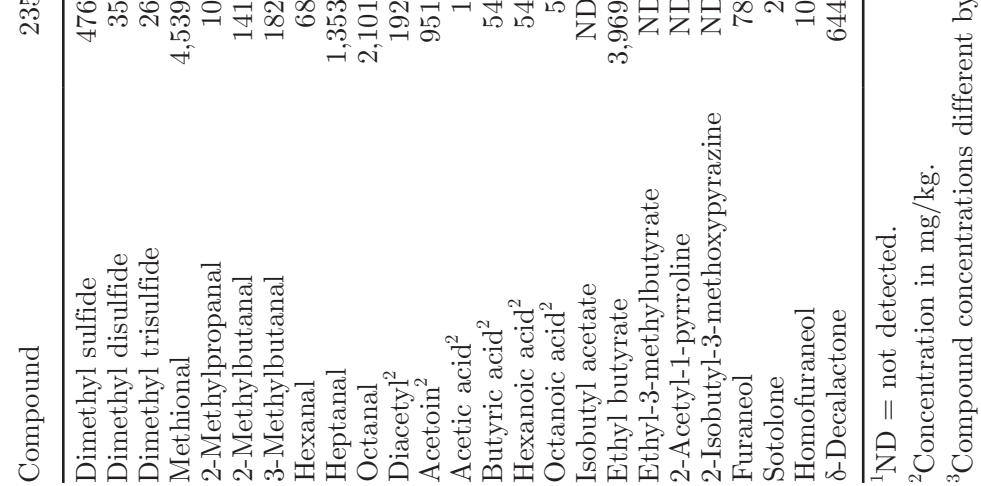


et al., 1997). Amino acid degradation in cheese is mainly attributable to the microbial enzymes involved with deamination, transamination, decarboxylation, and so on (McSweeney and Sousa, 2000). Chemical degradation by Strecker degradation can also occur during cheese ripening (Yvon et al., 1997). However, enzyme-catalyzed transamination is most likely to be the first step of AA degradation in cheese, which is subsequently degraded by decarboxylation or Strecker reaction, generating corresponding aldehydes (Yvon et al., 1997; McSweeney and Sousa, 2000). Branched-chain AA isoleucine, leucine, and valine are degraded by an aminotransferase or Strecker degradation and produce branched-chain aldehydes, 2- and 3-methylbutanal, and 2-methylpropanal, respectively (McSweeney and Sousa, 2000; Pripis-Nicolau et al., 2000; Yvon and Rijnen, 2001; Marilley and Casey, 2004). These aldehydes have been shown to contribute nutty, meaty, and cocoa flavors in cheeses (Yvon and Rijnen, 2001; Avsar et al., 2004).

Sulfur containing volatiles are known to have a significant effect on the flavor of numerous cheeses, including Cheddar, Swiss, and Parmesan (McSweeney and Sousa, 2000; Marilley and Casey, 2004). Sulfur compounds, dimethyl disulfide (DMDS), dimethyl trisulfide (DMTS), and methional originate from methionine as it is present at higher a concentration in casein than in cysteine (McSweeney and Sousa, 2000). Methional is produced from Strecker degradation of methionine; methanethiol, and its oxidative products DMDS and DMTS, are formed from an elimination reaction of methionine (McSweeney and Sousa, 2000; Yvon and Rijnen, 2001). Dimethyl sulfide is a product of the metabolism of methionine by propionic acid bacteria, but it could also be produced directly from methanethiol (McSweeney and Sousa, 2000). Methional, DMDS, and DMTS were previously identified as the key sulfur compounds present in Gouda-type cheeses (Van Leuven et al., 2008). There was a higher concentration of sulfur compounds in aged Gouda cheeses, and this could be correlated with increased brothy flavor in aged Gouda cheeses.

2-Isobutyl-3-methoxypyrazine imparts a bell pepperlike aroma in cheese and was a significant odorant in the earthy and bell pepper flavor of farmhouse Cheddar (Suriyaphan et al., 2001). It was present in 33 out of 36 Gouda cheeses in the current study. Methoxypyrazine has been attributed to microbial origin, especially molds, and is known for earthy and mushroom flavors in mold surface-ripened cheeses (Karahadian et al., 1985). Dunn and Lindsay (1985) reported that methoxypyrazines were formed by microbial-related Strecker degradation reactions in aged Cheddar cheese.
Murray and Whitfield (1975) suggested that valine, leucine, and isoleucine are precursors of corresponding methoxypyrazines because of similarities in the side chains. It is thought that enzymatic activity (e.g., methyltransferase) is involved with the formation of methoxypyrazine in vegetables and fruits (Dunlevy et al., 2009), but its specific role in cheese is not fully understood. 2-Acetyl-1-pyrroline has been reported as a key odorant in young Cheddar cheeses (Zehentbauer and Reineccius, 2002). 2-Acetyl-1-pyrroline has a popcorn aroma, possibly contributing to a sweet/cooked and milky flavor. 2-Acetyl-1-pyrroline is formed by Strecker degradation of proline and is readily formed even under mild heating (Reineccius, 2006; Belitz et al., 2009).

Furanones (furaneol, homofuraneol, and sotolone) were generally present at higher concentrations in international Gouda cheeses compared with US Gouda cheeses. Furanones increased with longer age time. The use of certain strains of lactobacilli or differences in nonstarter lactic acid bacteria could be associated with increases in furanones (Milo and Reineccius, 1997). Furanones are formed from the reaction of pentoses and hexoses with AA, glycine, and glutamate (Hayashida et al., 1999). Furanones impart burnt, caramel, and sweet flavors to cheese, but the increase of furanones in low-fat Cheddar cheeses can be associated with meaty or brothy flavor (Milo and Reineccius, 1997). Homofuraneol and furaneol were reported as primary contributors to the pleasant mild aroma of Cheddar cheese (Milo and Reineccius, 1997). Sotolon was previously identified in Cheddar, blue, and Parmesan cheeses (Frank et al., 2004).

\section{Sensory Analysis}

Descriptive Analysis. Principal component (PC) analysis was applied to flavor- and texture-trained panel profiles of Gouda cheeses (Figures 2 and 3). For flavor, PC 1 explained $42 \%$ of the variability and comprised sour aromatic, whey, sulfur, fruity, malty/nutty, caramel, and brothy flavors and sweet and umami taste attributes. Principal component 2 explained $12 \%$ of the variability and comprised milk fat, cooked, and cowy/ barny flavors. Sour taste and diacetyl flavor composed PC 3 and 4 (results not shown). For texture, PC 1 explained $64 \%$ of the variability and consisted of hand firmness, fracture, firmness (first bite), mouth coating, mass smoothness, cohesiveness, and adhesiveness. Principal component 2 explained $14 \%$ of the variability and consisted of hand springiness, hand recovery, and adhesiveness. Sixteen percent of the variability was explained by PC 3 and 4 for texture (results not shown). 
Principal component 3 explained $9 \%$ and comprised degree of breakdown, and PC 4 explained $7 \%$ and comprised fracture.

All Gouda cheeses had the following sensory attributes: cooked/milky, milk fat, brothy, sulfur, and sour aromatic flavors and sweet, sour, and umami tastes. Young and medium Gouda cheeses were characterized by whey, sour aromatic, cooked/milky, and diacetyl notes, whereas aged cheeses were differentiated by low intensities of caramel, brothy, malty/nutty, and fruity flavors and sweet, salty, and umami tastes (Figure 2). International cheeses were likely to be associated with cowy/barny or grassy flavors (Figure 2). This might be attributed to environmental differences, such as pasture type (Drake et al., 2005). Higher intensities of these flavors were observed in international cheeses 169 and 180, possibly due to a pasture-fed diet. Previous studies by Bendall (2001), Croissant et al. (2007), and Drake et al. (2005) have documented sensory and volatile differences in US versus international cheeses and milks. Bendall (2001) and Croissant et al. (2007) reported that flavor variability between pasture- and TMR-based milks resulted from concentration differences for the same compounds rather than from the presence of specific feed-, breed-, or plant-associated compounds. Sensory differences based on country of origin were documented between Irish, US, and New Zealand Cheddar cheeses by Drake et al. (2005), where non-US cheeses were distinguished by low but distinct intensities of cowy/barny or mothball flavors.

Aged Gouda cheeses $(212,267,235,520,608,612$, 620,629 , and 995) were distinct from younger Goudas (Figure 2). Young et al. (2004) and Drake et al. (2001) observed similar flavor differences in Cheddar cheeses based on age. Young Cheddar cheeses with less time for flavor development were characterized by milky, whey,

Biplot (axes PC1 and PC2: 54\%)

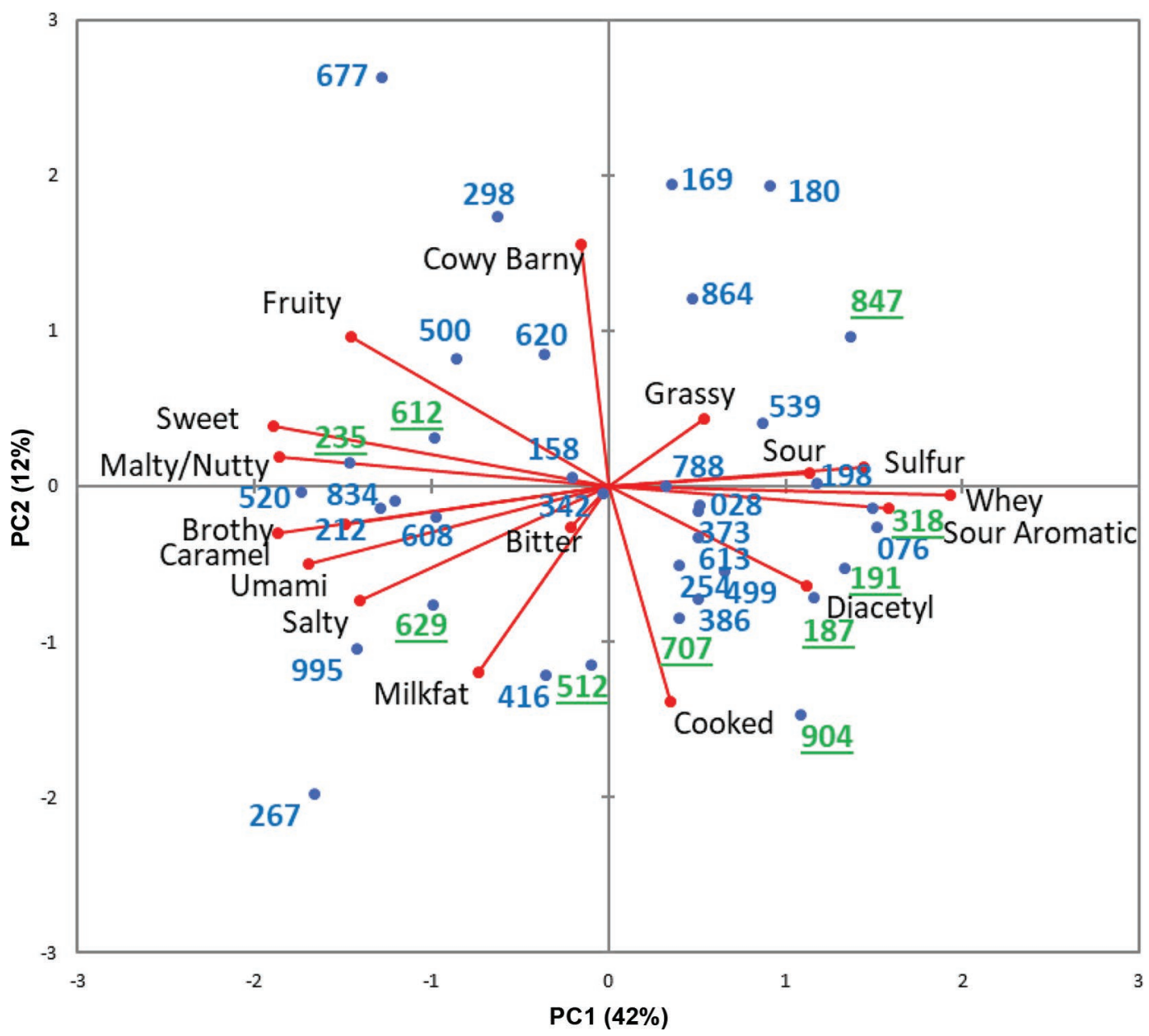

Figure 2. Principal component (PC) analysis biplot (PC 1 and 2) of flavor attributes of Gouda cheeses. Numbers represent Gouda cheeses, and underlined numbers were used for consumer testing. Color version available online. 
and diacetyl notes, and older cheeses were characterized by more complex flavors and higher basic taste intensities, including sulfur, brothy, caramel, nutty, umami, sour taste, and salty taste (Drake et al., 2001; Young et al., 2004). Van Leuven et al. (2008) previously observed similar decreases in creamy and buttery flavor attributes based on ripening time in Gouda cheese. Higher intensities of sweet and bitter tastes and flowery, fruity, nutty, chocolate, and animal flavors were documented in raw-milk Gouda cheeses compared with pasteurizedmilk cheeses. There were 3 raw-milk cheeses in the current study (187 at 5 mo, 500 at 10 mo, and 298 at $18 \mathrm{mo}$ ), and these raw-milk cheeses were differentiated from one another based on intensities of whey, fruity, and cowy/barny flavors. Gouda cheeses produced with raw milk were not consistently distinct from those produced with pasteurized milk, possibly due to several other factors (e.g., age, make procedure, or composition) that influence cheese flavor development.
Younger Gouda cheeses were characterized by higher intensities of hand springiness, hand recovery, mouth coating, smoothness of mass, and breakdown (Figure 3 ). Medium aged Gouda cheeses were higher in cohesiveness and adhesiveness, and aged Gouda cheeses were characterized by higher intensities of fracture, firmness in the mouth, and hand firmness that likely result from lower moisture content and breakdown of the protein matrix (Figure 3). Similar texture differences in firmness, fracture, mouth coating, smoothness, and breakdown based on age were previously reported in Gouda cheeses (Yates and Drake, 2007).

Focus Groups. Consumers stated that the flavor of Gouda cheese was what made it unique as a variety but were generally unable to describe the flavor profile. Most consumers expected Gouda to have a "creamy" (smooth and homogeneous) texture and light yellow color, but some consumers preferred dark-colored aged Gouda cheeses with a drier texture and crunchi-

Biplot (axes PC1 and PC2: 78\%)

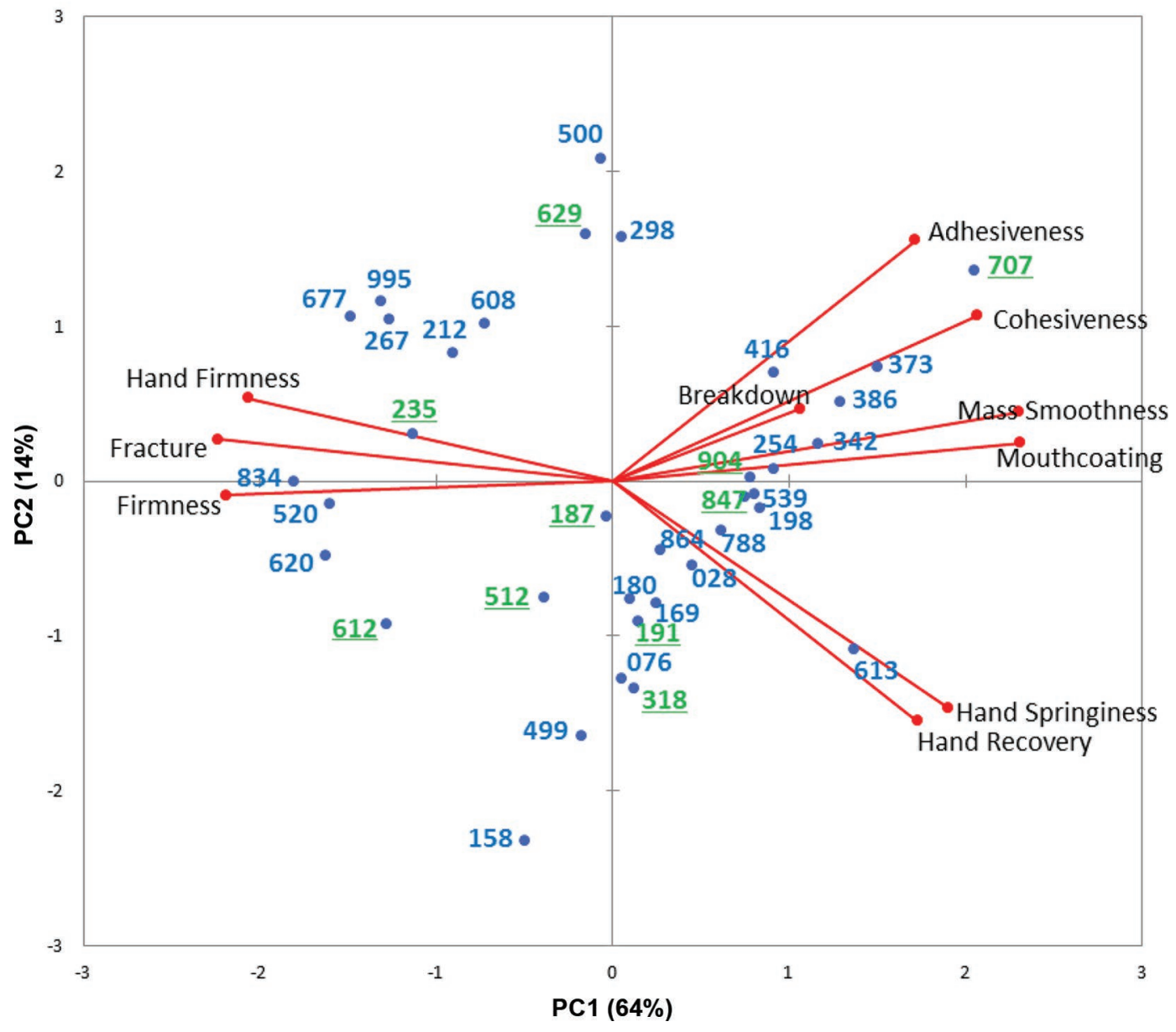

Figure 3. Principal component (PC) analysis biplot (PC 1 and 2) of texture attributes of Gouda cheeses. Numbers represent Gouda cheeses, and underlined numbers were used for consumer testing. Color version available online. 
ness imparted by crystals. More consumers classified Gouda as a specialty cheese than a daily cheese, but all consumers used Gouda cheese in numerous applications, including entertaining, snacking, sandwiches, and cooking. Although consumers were more familiar with wedge or wheel-shaped Gouda, they expressed interest in trying shredded, sliced, and block-format cheeses. Only 2 consumers (out of 35 across 3 focus groups) were aware that Gouda cheese originated in the Netherlands, and all consumers stated that they had no preference of European over American Gouda cheeses. Consumers stated that packaging appeal, quality, and age were more important when shopping for a new cheese than country of origin or nutritional content.

Consumer Acceptance Test. Cheeses 187, 512, 847, 318, and 904 received the highest overall liking score across all consumers (Table 7 ). These cheeses were
US young or medium Gouda cheeses aged less than 6 mo. Aged Gouda cheeses 235, 612, and 629 scored lower in overall liking across all consumers. Based on JAR scores, these cheeses were too high in flavor, too salty, too firm, and not creamy enough for consumers. Overall appearance, flavor, and texture liking scores were consistent with consumer focus group themes. Color, saltiness, firmness, and creaminess liking as well as flavor intensity were correlated $\left(\mathrm{R}^{2}>0.95\right)$ with overall liking of cheeses $(P<0.05)$.

Overall drivers of liking for all consumers $(\mathrm{n}=149)$ included whey, diacetyl, and sulfur flavors; sour taste; springy, smooth texture; and moderate mouth coating and degree of breakdown. Drivers of dislike for all consumers included fruity, malty/nutty, caramel, brothy, and milk fat flavors and salty, sweet, bitter, and umami tastes. Three distinct consumer segments were identi-

Table 7. Overall liking attribute means from consumer acceptance testing of selected Gouda cheeses ${ }^{1}$

\begin{tabular}{|c|c|c|c|c|c|c|c|c|c|c|}
\hline \multirow[b]{2}{*}{ Item } & \multicolumn{10}{|c|}{ Sample } \\
\hline & 235 & 612 & 629 & 707 & 847 & 187 & 318 & 904 & 191 & 512 \\
\hline \multicolumn{11}{|l|}{ Liking $^{2}$} \\
\hline Aroma & $6.1^{\mathrm{d}}$ & $5.6^{\mathrm{e}}$ & $5.2^{\mathrm{f}}$ & $6.2^{\mathrm{d}}$ & $6.8^{\mathrm{a}}$ & $6.3^{\mathrm{cd}}$ & $6.4^{\text {bcd }}$ & $6.7^{\mathrm{ab}}$ & $5.5^{\mathrm{ef}}$ & $6.6^{\mathrm{abc}}$ \\
\hline Appearance & $6.7^{\mathrm{bc}}$ & $5.6^{\mathrm{d}}$ & $5.0^{\mathrm{e}}$ & $6.6^{\mathrm{c}}$ & $7.1^{\mathrm{a}}$ & $6.9^{\mathrm{abc}}$ & $6.7^{\mathrm{bc}}$ & $7.0^{\mathrm{ab}}$ & $6.6^{\mathrm{c}}$ & $6.7^{\mathrm{bc}}$ \\
\hline Overall & $5.7^{\mathrm{b}}$ & $4.2^{\mathrm{c}}$ & $4.2^{\mathrm{c}}$ & $5.7^{\mathrm{b}}$ & $6.7^{\mathrm{a}}$ & $6.8^{\mathrm{a}}$ & $6.5^{\mathrm{a}}$ & $6.6^{\mathrm{a}}$ & $5.7^{\mathrm{b}}$ & $6.9^{\mathrm{a}}$ \\
\hline Color & $6.7^{\mathrm{abc}}$ & $5.9^{\mathrm{d}}$ & $5.1^{\mathrm{e}}$ & $6.6^{\mathrm{bc}}$ & $6.9^{\mathrm{ab}}$ & $6.7^{\mathrm{abc}}$ & $6.4^{\mathrm{c}}$ & $7.0^{\mathrm{a}}$ & $6.3^{\mathrm{c}}$ & $6.4^{\mathrm{c}}$ \\
\hline Flavor & $5.7^{\mathrm{c}}$ & $4.2^{\mathrm{d}}$ & $4.2^{\mathrm{d}}$ & $5.6^{\mathrm{c}}$ & $6.6^{\mathrm{ab}}$ & $6.8^{\mathrm{a}}$ & $6.6^{\mathrm{ab}}$ & $6.2^{\mathrm{b}}$ & $5.4^{\mathrm{c}}$ & $6.9^{\mathrm{a}}$ \\
\hline Saltiness & $5.5^{\mathrm{c}}$ & $4.7^{\mathrm{d}}$ & $4.8^{\mathrm{d}}$ & $5.6^{\mathrm{c}}$ & $6.4^{\mathrm{a}}$ & $6.4^{\mathrm{a}}$ & $6.1^{\mathrm{ab}}$ & $5.9^{\mathrm{bc}}$ & $5.5^{\mathrm{c}}$ & $6.4^{\mathrm{a}}$ \\
\hline Texture & $5.4^{\mathrm{d}}$ & $4.2^{\mathrm{e}}$ & $4.0^{\mathrm{e}}$ & $6.2^{\mathrm{c}}$ & $6.7^{\mathrm{abc}}$ & $6.6^{\mathrm{abc}}$ & $6.7^{\mathrm{abc}}$ & $7.0^{\mathrm{a}}$ & $6.4^{\mathrm{bc}}$ & $6.7^{\mathrm{ab}}$ \\
\hline Creaminess & $5.3^{\mathrm{c}}$ & $3.9^{\mathrm{d}}$ & $4.0^{\mathrm{d}}$ & $6.3^{\mathrm{b}}$ & $6.9^{\mathrm{a}}$ & $6.7^{\mathrm{ab}}$ & $6.7^{\mathrm{ab}}$ & $7.1^{\mathrm{a}}$ & $6.3^{\mathrm{b}}$ & $6.7^{\mathrm{ab}}$ \\
\hline \multicolumn{11}{|l|}{ JAR questions ${ }^{3}$} \\
\hline \multicolumn{11}{|l|}{ Flavor $(\%)$} \\
\hline Not enough flavor & $6.0^{\text {cde }}$ & $2.7^{\mathrm{de}}$ & $1.3^{\mathrm{e}}$ & $18.8^{\mathrm{abc}}$ & $28.2^{\mathrm{ab}}$ & $15.4^{\mathrm{abcd}}$ & $34.2^{\mathrm{a}}$ & $17.4^{\mathrm{abc}}$ & $14.8^{\mathrm{abcd}}$ & $13.4^{\mathrm{bcde}}$ \\
\hline JAR & $49.0^{\mathrm{bcd}}$ & $34.2^{\mathrm{cd}}$ & $30.2^{\mathrm{d}}$ & $51.7^{\text {abcd }}$ & $61.1^{\mathrm{ab}}$ & $72.5^{\mathrm{a}}$ & $57.0^{\mathrm{abc}}$ & $56.4^{\mathrm{abc}}$ & $50.3^{\mathrm{abcd}}$ & $67.1^{\mathrm{ab}}$ \\
\hline Too much flavor & $45.0^{\mathrm{bc}}$ & $63.1^{\mathrm{ab}}$ & $68.5^{\mathrm{a}}$ & $29.5^{\text {cde }}$ & $10.7^{\mathrm{f}}$ & $12.1^{\text {ef }}$ & $8.7^{\mathrm{f}}$ & $26.2^{\text {cdef }}$ & $34.9^{\mathrm{cd}}$ & $19.5^{\text {def }}$ \\
\hline \multicolumn{11}{|l|}{ Color $(\%)$} \\
\hline Too light & $18.8^{\mathrm{bc}}$ & $8.1^{\mathrm{cd}}$ & $2.7^{\mathrm{d}}$ & $12.8^{\mathrm{cd}}$ & $32.9^{\mathrm{ab}}$ & $34.2^{\mathrm{ab}}$ & $43.6^{\mathrm{a}}$ & $7.4^{\mathrm{cd}}$ & $44.3^{\mathrm{a}}$ & $2.7^{\mathrm{d}}$ \\
\hline JAR & $77.2^{\mathrm{ab}}$ & $61.7^{\mathrm{ab}}$ & $32.2^{\mathrm{c}}$ & $73.8^{\mathrm{ab}}$ & $67.1^{\mathrm{ab}}$ & $64.4^{\mathrm{ab}}$ & $56.4^{\mathrm{b}}$ & $81.2^{\mathrm{a}}$ & $55.7^{\mathrm{b}}$ & $65.1^{\mathrm{ab}}$ \\
\hline Too dark & $4.0^{\mathrm{de}}$ & $30.2^{\mathrm{bc}}$ & $65.1^{\mathrm{a}}$ & $13.4^{\mathrm{bcd}}$ & $0.0 \mathrm{f}$ & $1.3^{\text {de }}$ & $0.0^{\mathrm{f}}$ & $11.4^{\mathrm{cd}}$ & $0.0^{\mathrm{f}}$ & $32.2^{\mathrm{b}}$ \\
\hline \multicolumn{11}{|l|}{ Saltiness (\%) } \\
\hline Not salty enough & $10.7^{\mathrm{a}}$ & $8.7^{\mathrm{a}}$ & $5.4^{\mathrm{a}}$ & $10.7^{\mathrm{a}}$ & $14.1^{\mathrm{a}}$ & $8.7^{\mathrm{a}}$ & $16.8^{\mathrm{a}}$ & $16.1^{\mathrm{a}}$ & $12.1^{\mathrm{a}}$ & $11.4^{\mathrm{a}}$ \\
\hline JAR & $58.4^{\mathrm{cd}}$ & $49.7^{\mathrm{c}}$ & $51.0^{\mathrm{c}}$ & $60.4^{\mathrm{abc}}$ & $80.5^{\mathrm{a}}$ & $75.2^{\mathrm{ab}}$ & $66.4^{\mathrm{abc}}$ & $65.1^{\mathrm{abc}}$ & $53.7^{\mathrm{cd}}$ & $69.8^{\mathrm{abc}}$ \\
\hline Too salty & $30.9^{\mathrm{ab}}$ & $41.6^{\mathrm{a}}$ & $43.6^{\mathrm{a}}$ & $28.9^{\mathrm{ab}}$ & $5.4^{\mathrm{c}}$ & $16.1^{\mathrm{bc}}$ & $16.8^{\mathrm{bc}}$ & $18.8^{\mathrm{bc}}$ & $34.2^{\mathrm{ab}}$ & $18.8^{\mathrm{bc}}$ \\
\hline \multicolumn{11}{|l|}{ Texture (\%) } \\
\hline Too soft & $3.4^{\mathrm{c}}$ & $2.7^{\mathrm{c}}$ & $0.7^{\mathrm{c}}$ & $28.9^{\mathrm{ab}}$ & $32.9^{\mathrm{ab}}$ & $10.1^{\mathrm{bc}}$ & $6.0^{\mathrm{bc}}$ & $21.5^{\mathrm{ab}}$ & $7.4^{\mathrm{bc}}$ & $8.7^{\mathrm{bc}}$ \\
\hline JAR & $51.0^{\mathrm{bc}}$ & $30.9^{\mathrm{cd}}$ & $28.2^{\mathrm{d}}$ & $60.4^{\mathrm{abc}}$ & $67.1^{\mathrm{ab}}$ & $64.4^{\mathrm{ab}}$ & $71.8^{\mathrm{ab}}$ & $77.9^{\mathrm{a}}$ & $71.8^{\mathrm{ab}}$ & $75.2^{\mathrm{a}}$ \\
\hline Too firm & $45.6^{\mathrm{bc}}$ & $66.4^{\mathrm{ab}}$ & $71.1^{\mathrm{a}}$ & $10.7^{\text {ed }}$ & $0.0^{\mathrm{g}}$ & $25.5^{\mathrm{cd}}$ & $22.1^{\mathrm{d}}$ & $0.7^{\text {ef }}$ & $20.8^{\mathrm{d}}$ & $16.1^{\mathrm{d}}$ \\
\hline \multicolumn{11}{|l|}{ Creaminess $(\%)$} \\
\hline Not creamy enough & $48.3^{\mathrm{ab}}$ & $64.4^{\mathrm{a}}$ & $65.8^{\mathrm{a}}$ & $12.8^{\mathrm{bc}}$ & $3.4^{\mathrm{c}}$ & $24.2^{\mathrm{b}}$ & $20.1^{\mathrm{b}}$ & $4.7^{\mathrm{c}}$ & $24.8^{\mathrm{b}}$ & $24.2^{\mathrm{b}}$ \\
\hline JAR & $47.0^{\mathrm{bc}}$ & $31.5^{\mathrm{c}}$ & $30.9^{\mathrm{c}}$ & $65.1^{\mathrm{bc}}$ & $73.2^{\mathrm{a}}$ & $69.1^{\mathrm{bc}}$ & $73.8^{\mathrm{a}}$ & $78.5^{\mathrm{a}}$ & $69.1^{\mathrm{bc}}$ & $71.1^{\mathrm{a}}$ \\
\hline Too creamy & $4.7^{\mathrm{c}}$ & $4.0^{\mathrm{c}}$ & $3.4^{\mathrm{c}}$ & $2.1^{\mathrm{ab}}$ & $23.5^{\mathrm{a}}$ & $6.7^{\mathrm{bc}}$ & $6.0^{\mathrm{bc}}$ & $16.8^{\mathrm{abc}}$ & $6.0^{\mathrm{bc}}$ & $4.7^{\mathrm{c}}$ \\
\hline Purchase intent ${ }^{4}$ & $3.0^{\mathrm{bc}}$ & $2.3^{\mathrm{d}}$ & $2.2^{\mathrm{d}}$ & $2.9^{\mathrm{c}}$ & $3.5^{\mathrm{ab}}$ & $3.8^{\mathrm{a}}$ & $3.5^{\mathrm{a}}$ & $3.4^{\mathrm{abc}}$ & $2.9^{\mathrm{c}}$ & $3.6^{\mathrm{a}}$ \\
\hline
\end{tabular}

${ }^{\text {a-g }}$ Means within a row with different superscripts are significantly different $(P<0.05)$.

${ }^{1}$ Data represent 149 consumers.

${ }^{2}$ Liking attributes were scored on a 9 -point hedonic scale, where $1=$ dislike extremely and $9=$ like extremely.

${ }^{3}$ Just-about-right (JAR) questions were scored on a 5 -point scale, where 1 or $2=$ too little, $3=$ just about right, and 4 or $5=$ too much. The percentage of consumers who selected these options is presented.

${ }^{4}$ Purchase intent was scored on a 5 -point scale, where $1=$ definitely would not buy, $2=$ probably would not buy, $3=$ may or may not buy, $4=$ probably would buy, and $5=$ definitely would buy. 
fied from consumer liking scores. Consumers in cluster $1(\mathrm{n}=27)$ were driven by a liking for aged cheeses with fruity, caramel, brothy, and malty/nutty flavors and sweet and umami tastes. Cluster 1 consumers disliked younger cheeses with springy texture, whey and sulfur flavors, and sour taste (Figure 4). Both clusters $2(\mathrm{n}=65)$ and $3(\mathrm{n}=57)$ liked young and medium cheeses characterized by diacetyl and cooked/milky flavors. Differences between consumers in clusters 2 and 3 were their liking of aged cheeses (Table 8). Based on the overall liking scores across all clusters (Table 8 ), consumers in cluster 2 disliked aged cheeses (612 and 629), whereas cluster 3 consumers liked almost all cheeses regardless of age. Cluster 1 scored higher liking for cheeses 235 and 629, which were characterized by aged flavors, including malty/nutty, fruity, caramel flavors; salty, sweet, and umami tastes; and firm texture. Liking scores from cluster 2 consumers were higher for cheeses 187, 191, 904, and 318. These cheeses were characterized by younger cheese flavors, including diacetyl, whey, cooked, sulfur, and sour aromatic flavors; a springy texture; and a high degree of recovery (Figures 2 and 3). Cluster 3 liking scores were higher for most cheeses. However, their preference for cheeses 512 and 707 was significantly higher compared with consumers in clusters 1 and $2(P<0.05)$. These were

PC1 and PC2 55\%

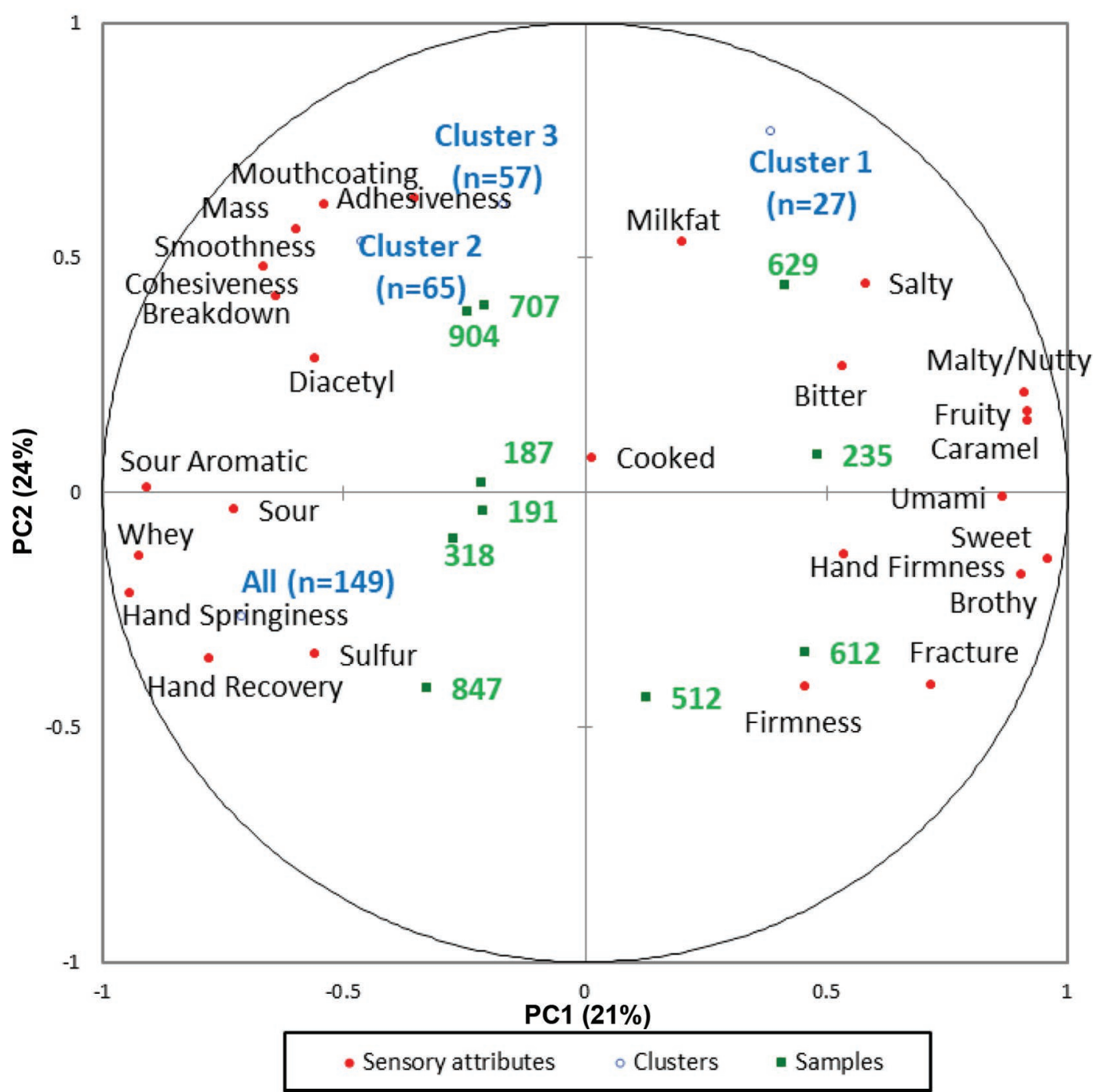

Figure 4. Partial least squares correlation biplot (principal components 1 and 2) of trained panel and consumer liking scores. Flavor and texture attributes are included in this biplot. Numbers represent cheeses that were included in consumer testing. Color version available online. 
Table 8. Overall liking means for Gouda cheeses for each cluster ${ }^{1}$

\begin{tabular}{lccc}
\hline & \multicolumn{3}{c}{ Cluster } \\
\cline { 2 - 4 } Sample & $1(\mathrm{n}=27)$ & $2(\mathrm{n}=65)$ & $3(\mathrm{n}=57)$ \\
\hline 235 & $7.0^{\mathrm{a}}$ & $6.7^{\mathrm{a}}$ & $6.8^{\mathrm{a}}$ \\
612 & $6.0^{\mathrm{a}}$ & $4.9^{\mathrm{b}}$ & $6.5^{\mathrm{a}}$ \\
629 & $7.0^{\mathrm{a}}$ & $5.6^{\mathrm{b}}$ & $6.4^{\mathrm{a}}$ \\
707 & $2.8^{\mathrm{b}}$ & $2.3^{\mathrm{b}}$ & $7.0^{\mathrm{a}}$ \\
847 & $3.6^{\mathrm{b}}$ & $6.3^{\mathrm{a}}$ & $6.1^{\mathrm{a}}$ \\
187 & $5.8^{\mathrm{b}}$ & $6.9^{\mathrm{a}}$ & $6.7^{\mathrm{a}}$ \\
318 & $3.4^{\mathrm{c}}$ & $6.8^{\mathrm{a}}$ & $5.6^{\mathrm{b}}$ \\
904 & $6.7^{\mathrm{a}}$ & $7.0^{\mathrm{a}}$ & $7.0^{\mathrm{a}}$ \\
191 & $5.9^{\mathrm{b}}$ & $7.0^{\mathrm{a}}$ & $6.8^{\mathrm{a}}$ \\
512 & $4.0^{\mathrm{b}}$ & $2.6^{\mathrm{c}}$ & $6.3^{\mathrm{a}}$ \\
\hline
\end{tabular}

${ }^{\mathrm{a}-c}$ Means within a row with different superscripts are significantly different $(P<0.05)$.

${ }^{1}$ Liking attributes were scored on a 9 -point hedonic scale, where $1=$ dislike extremely and $9=$ like extremely.

young and medium cheeses characterized by intense cooked/milky and milk fat flavors (Figure 2). These results indicate that young and medium Gouda cheeses are liked by all consumers but that aged Gouda cheeses are preferred by one consumer group.

Previous studies concerning consumer acceptance of Cheddar, Edam, and Gouda cheeses have identified similar drivers of liking and consumer clusters based on flavor and texture preferences (Murray and Delahunty, 2000; Young et al., 2004; Ritvanen et al., 2005). Cheddar cheese consumer clusters previously identified by Young et al. (2004) and Murray and Delahunty (2000) differed based on preferences for mature cheeses with higher intensities of salty taste, flavor strength, and crumbliness versus liking of younger cheeses characterized by sweet taste and buttery flavor. Ritvanen et al. (2005) investigated Finnish consumer liking of Edam cheeses and found that appearance, mouthfeel, and flavor were strongly correlated with overall liking. Edam cheeses with high overall liking were characterized by richness of flavor, salty taste, creaminess, flavor intensity, and even appearance of holes, but no consumer clusters were investigated for these consumers (Ritvanen et al., 2005). Yates and Drake (2007) reported that both flavor and texture were important to consumer liking of Gouda cheeses, but an undesirable texture cannot be compensated for by a liking of flavor, confirming the importance of cheese texture. For the current study and the Yates and Drake (2007) study, creaminess was correlated with higher overall liking for Gouda cheeses, and fracturability was correlated with lower overall liking scores across all consumers $\left(\mathrm{R}^{2}>0.93\right)$. This study established the chemical and sensory differences of Gouda cheeses that may differentiate key odorants and perceived flavor and further influence drivers of liking of Gouda cheese.

\section{CONCLUSIONS}

A wide range of Gouda cheeses were characterized by composition, volatile compounds, descriptive analysis, and consumer acceptance. Major differences observed among Gouda cheeses were primarily due to age. Based on frequency and aroma character, 6 aroma-active compounds can be considered characteristic to all Gouda cheeses: diacetyl, 2- and 3-methylbutanal, methional, ethyl butyrate, and acetic acid. Five additional compounds can be considered characteristic to aged Gouda cheeses: 2-methylpropanal, butyric acid, homofuraneol, $\delta$-decalactone, and 2-isopropyl-3-methoxypyrazine. Younger cheeses were lighter in color and less intense in flavor and basic tastes and had a creamier and moister texture compared with aged cheeses. Aged cheeses had higher concentrations of flavor compounds and flavor intensities with a more firm and fracturable texture. Young and medium cheeses were most appealing to US consumers. Generally, consumers preferred Gouda cheese with a lighter color, whey, diacetyl flavors, and sour taste. In terms of texture, a Gouda cheese with a springy, smooth texture and moderate mouth coating and degree of breakdown was most appealing. Aged Gouda cheeses were preferred by one consumer group, but one consumer segment that assigned a high liking score to all Gouda cheeses also had a preference for the flavors and textures of aged Gouda cheeses. These findings can help US manufacturers understand the flavors and textures that are characteristic to this cheese variety and how to create a Gouda cheese with optimal sensory properties for US consumers.

\section{ACKNOWLEDGMENTS}

Funding was provided in part by the National Dairy Council (Rosemont, IL). The use of trade names does not imply endorsement or lack of endorsement of those not mentioned.

\section{REFERENCES}

Alewijn, M., E. L. Sliwinski, and J. T. M. Wouters. 2005. Production of fat-derived (flavour) compounds during the ripening of Gouda cheese. Int. Dairy J. 15:733-740.

Alewijn, M., B. A. Smit, E. L. Sliwinski, and J. T. M. Wouters. 2007. The formation mechanism of lactones in Gouda cheese. Int. Dairy J. $17: 59-66$.

AOAC International. 2000. Official Methods of Analysis. 17th ed. AOAC International, Gaithersburg, MD.

Arora, G., F. Cormier, and B. Lee. 1995. Analysis of odor-active volatiles in Cheddar cheese headspace by multidimensional GC/MS/ sniffing. J. Agric. Food Chem. 43:748-752.

Avsar, Y. K., Y. Karagul-Yuceer, M. A. Drake, T. Singh, Y. Yoon, and K. R. Cadwallader. 2004. Characterization of nutty flavor in Cheddar cheese. J. Dairy Sci. 87:1999-2010. 
Belitz, H.-D., W. Grosch, and P. Schieberle. 2009. Aroma compounds. Pages 340-402 in Food Chemistry. 4th ed. Springer, Heidelberg, Germany.

Bendall, J. G. 2001. Aroma compounds of fresh milk from New Zealand cows fed different diets. J. Agric. Food Chem. 49:4825-4832.

Bradley, R. L., and M. A. Vanderwarn. 2001. Determination of moisture in cheese and cheese products. J. AOAC Int. 84:570-592.

Brown, J. A., E. A. Foegeding, C. R. Daubert, M. A. Drake, and M. Gumpertz. 2003. Relationships among rheological and sensorial properties of young cheeses. J. Dairy Sci. 86:3054-3067.

Cadwallader, K. R., and T. K. Singh. 2009. Flavours and off-flavours in milk and dairy products. Pages 631-690 in Advanced Dairy Chemistry. Vol 3. P. McSweeney and P. F. Fox, ed. Springer, New York, NY.

Califano, A. N., and A. E. Bevilacqua. 2000. Multivariate analysis of the organic acids content of Gouda type cheese during ripening. J. Food Compos. Anal. 13:949-960.

Carunchia Whetstine, M. E., A. E. Croissant, and M. A. Drake. 2005 Characterization of dried whey protein concentrate and isolate flavor. J. Dairy Sci. 88:3826-3839.

Childs, J. L., and M. A. Drake. 2009. Consumer perception of fat reduction in cheese. J. Sens. Stud. 24:902-921.

Codex Alimentarius. 2013. Standard for Gouda. Codex standard 2661966. Food and Agriculture Organization of the United Nations (FAO) and World Health Organization (WHO), Geneva, Switzerland.

Collins, Y. F., P. McSweeney, and M. G. Wilkinson. 2003. Lipolysis and free fatty acid catabolism in cheese: A review of current knowledge. Int. Dairy J. 13:841-866.

Corzo, N., M. Villamiel, M. Arias, S. Jimenez-Perez, and F. J. Morales. 2000. The Maillard reaction during the ripening of Manchego cheese. Food Chem. 71:255-258.

Croissant, A. E., S. P. Washburn, L. L. Dean, and M. A. Drake. 2007. Chemical properties and consumer perception of fluid milk from conventional and pasture-based production systems. J. Dairy Sci. 90:4942-4953.

Curioni, P. M. G., and J. O. Bosset. 2002. Key odorants in various cheese types as determined by gas chromatography-olfactometry. Int. Dairy J. 12:959-984.

d'Acampora Zellner, B. A., P. Dugo, G. Dugo, and L. Mondello. 2008. Gas chromatography-olfactometry in food flavour analysis. J. Chromatogr. A 1186:123-143.

Desai, N. T., L. Shepard, and M. A. Drake. 2013. Sensory properties and drivers of liking for Greek yogurts. J. Dairy Sci. 96:7454-7466.

Dimos, A., G. E. Urbach, and A. J. Miller. 1996. Changes in flavor and volatiles of full fat and low fat cheeses during maturation. Int. Dairy J. 6:981-995.

Dirinck, P., and A. De Winne. 1999. Flavour characterisation and classification of cheeses by gas chromatographic-mass spectrometric profiling. J. Chromatogr. A 847:203-208.

Drake, M. A. 2004. ADSA foundation scholar award: Defining dairy flavors. J. Dairy Sci. 87:777-784.

Drake, M. A. 2007. Defining cheese flavor. Pages 370-395 in Improving the Flavour of Cheese. B. C. Weimer, ed. CRC Press, Boca Raton, FL.

Drake, M. A., S. C. Mcingvale, P. D. Gerard, K. R. Cadwallader, and G. V. Civille. 2001. Development of a descriptive language for Cheddar cheese. J. Food Sci. 66:1422-1427.

Drake, M. A., R. E. Miracle, and D. J. McMahon. 2010. Impact of fat reduction on flavor and flavor chemistry of Cheddar cheeses. J. Dairy Sci. 93:5069-5081.

Drake, M. A., M. D. Yates, P. D. Gerard, C. M. Delahunty, E. M. Sheehan, R. P. Turnbull, and T. M. Dodds. 2005. Comparison of differences between lexicons for descriptive analysis of Cheddar cheese flavour in Ireland, New Zealand, and the United States of America. Int. Dairy J. 15:473-483.

Drake, S. L., P. D. Gerard, and M. A. Drake. 2008. Consumer preferences for mild Cheddar cheese flavors. J. Food Sci. 73:S449-S455.

Drake, S. L., K. Lopetcharat, and M. A. Drake. 2009. Comparison of two methods to explore consumer preferences for cottage cheese. J. Dairy Sci. 92:5883-5897.
Du, X., C. E. Finn, and M. C. Qian. 2010. Volatile composition and odour-activity value of thornless "Black Diamond" and "Marion" blackberries. J. Food Chem. 119:1127-1134.

Dufosse, L., and M. C. De Echanove. 2005. The last step in the biosynthesis of aryl carotenoids in the cheese ripening bacteria Brevibacterium linens ATCC 9175 (Brevibacterium aurantiacum sp. nov.) involves a cytochrome P450-dependent monooxygenase. Food Res. Int. 38:967-973.

Dunlevy, J. D., C. M. Kalua, R. A. Keyzers, and P. K. Boss. 2009 The production of flavour and aroma compounds in grape berries. Pages 293-340 in Grapevine Molecular Physiology and Biotechnology. K. A. Roubelakis-Angelakis, ed. Springer, Dordrecht, the Netherlands.

Dunn, H. C., and R. C. Lindsay. 1985. Evaluation of the role of microbial Strecker-derived aroma compounds in uncleaned-type flavors of Cheddar cheese. J. Dairy Sci. 68:2859-2874.

El-Nimr, A., H. A. Eissa, M. M. El-Abd, A. A. Mehriz, H. M. Abbas, and H. M. Bayoumi. 2010. Water activity, color characteristics and sensory properties of Egyptian Gouda cheese during ripening. J Am. Sci. 6:447-453.

El Soda, M. A. 1993. The role of lactic acid bacteria in accelerated cheese ripening. FEMS Microbiol. Rev. 12:239-252.

Fox, P. F., T. P. Guinee, T. M. Cogan, and P. L. H. McSweeney. 2000. Biochemistry of cheese ripening. Pages 391-439 in Fundamentals of Cheese Science. P. F. Fox, T. P. Guinee, T. M. Cogan, and P. L. H. McSweeney, ed. Springer, New York, NY.

Frank, D. C., C. M. Owen, and J. Patterson. 2004. Solid phase microextraction (SPME) combined with gas-chromatography and olfactometry-mass spectrometry for characterization of cheese aroma compounds. Lebensm. Wiss. Technol. 37:139-154.

Hayashida, Y., H. Kuriyama, K. Nishimura, and J. C. Slaughter. 1999 Production of 4-hydroxyfuranones in simple media by fermentation. Biotechnol. Lett. 21:505-509.

Holland, R., S.-Q. Liu, V. L. Crow, M.-L. Delabre, M. Lubbers, M. Bennett, and G. Norris. 2005. Esterases of lactic acid bacteria and cheese flavour: Milk fat hydrolysis, alcoholysis and esterification. Int. Dairy J. 15:711-718.

Holland, R., S.-Q. Liu, T. Wang, and M. Bennett. 2002. Esterases of lactic acid bacteria. Aust. J. Dairy Technol. 57:116.

Inagaki, S., S. Fujikawa, Y. Wada, and K. Kumazawa. 2015. Identification of the possible new odor-active compounds "12-methyltridecanal and its analogs" responsible for the characteristic aroma of ripe Gouda-type cheese. Biosci. Biotechnol. Biochem. 79:2050-2056.

Iyer, M., T. Richardson, C. H. Amundson, and A. Boudreau. 1967 Improved technique for analysis of free fatty acids in butteroil and provolone cheese. J. Dairy Sci. 50:285-291.

Jung, H. J., P. Ganesan, S. J. Lee, and H. S. Kwak. 2013. Comparative study of flavor in cholesterol-removed Gouda cheese and Gouda cheese during ripening. J. Dairy Sci. 96:1972-1983.

Karahadian, C., D. B. Josephson, and R. C. Lindsay. 1985. Volatile compounds from Penicillium sp. contributing musty-earthy notes to Brie and Camembert cheese flavors. J. Agric. Food Chem. 33:339-343.

Kumar, V., V. Sharma, and B. S. Sector. 2006. Effect of ripening on total conjugated linoleic acid and its isomers in buffalo cheddar cheese. Int. J. Dairy Technol. 59:257-260.

Marilley, L., and M. G. Casey. 2004. Flavours of cheese products: Metabolic pathways, analytical tools and identification of producing strains. Int. J. Food Microbiol. 90:139-159.

McSweeney, P. L. H., and M. J. Sousa. 2000. Biochemical pathways for the production of flavour compounds in cheeses during ripening: A review. Lait 80:293-324.

Meilgaard, M. C. G. V. Civille, and B. T. Carr. 2007. The Spectrum $^{\text {TM }}$ descriptive analysis method. Pages 189-253 in Sensory Evaluation Techniques. M. C. Meilgaard, G. V. Civille, and B. T. Carr, ed. CRC Press, Boca Raton, FL.

Mellgren, J. 2005. All cheese considered: Gouda. Bus. Source Complete 26:11-19.

Milo, C., and G. A. Reineccius. 1997. Identification and quantification of potent odorants in regular-fat and low-fat mild Cheddar cheese. J. Agric. Food Chem. 45:3590-3594. 
Moskowitz, H. R., and B. Krieger. 1995. The contribution of sensory liking to overall liking: An analysis of six food categories. Food Qual. Prefer. 6:83-90.

Murray, J. M., and C. M. Delahunty. 2000. Mapping consumer preference for the sensory and packaging attributes of Cheddar cheese. Food Qual. Prefer. 11:419-435.

Murray, K. E., and F. B. Whitfield. 1975. Occurrence of 3-alkyl-2-methoxypyrazines in raw vegetables. J. Sci. Food Agric. 26:973-986.

NIST (National Institute of Standards and Technology). 2014. NIST Wiley Registry: NIST Mass Spectral Library. 11th ed. Wiley, Hoboken, NJ.

Olson, N. F. 1990. The impact of lactic acid bacteria on cheese flavor. FEMS Microbiol. Rev. 87:131-148.

Pillonel, L., S. Ampuero, R. Tabacchi, and J. O. Bosset. 2003. Analytical methods for the determination of the geographic origin of Emmental cheese: Volatile compounds by GC/MS-FID and electronic nose. Eur. Food Res. Technol. 216:179-183.

Preininger, M., R. Warmke, and W. Grosch. 1996. Identification of the character impact flavour compounds of Swiss cheese by sensory studies of models. Eur. Food Res. Technol. 202:30-34.

Pripis-Nicolau, L., G. de Revel, A. Bertrand, and A. Maujean. 2000. Formation of flavor components by the reaction of amino acid and carbonyl compounds in mild conditions. J. Agric. Food Chem. 48:3761-3766.

Rehman, S.-U., J. M. Banks, E. Y. Brechany, D. D. Muir, P. L. H. McSweeney, and P. F. Fox. 2000. Influence of ripening temperature on the volatiles profile and flavour of Cheddar cheese made from raw or pasteurised milk. Int. Dairy J. 10:55-65.

Reineccius, G. A. 2006. Changes in food flavor due to processing. Pages 103-137 in Flavor Chemistry and Technology. 2nd ed. G. A. Reineccius, ed. CRC Press, Boca Raton, FL.

Ritvanen, T., S. Lampolahti, L. Lilleberg, T. Tupasela, M. Isoneimi, U. Appelbye, T. Lyytikainen, S. Eerola, and E. Uusi-Rauva. 2005. Sensory evaluation, chemical composition and consumer acceptance of full fat and reduced fat cheeses in the Finnish market. Food Qual. Prefer. 16:479-492.

Shepard, L., R. E. Miracle, P. Leksrisompong, and M. A. Drake. 2013. Relating sensory and chemical properties of sour cream to consumer acceptance. J. Dairy Sci. 96:5435-5454.

Singh, T. K., M. A. Drake, and K. R. Cadwallader. 2003. Flavor of Cheddar cheese: A chemical and sensory perspective. Compr. Rev. Food Sci. Food Saf. 2:166-189.

Skeie, S., C. Lindberg, and J. Narvhus. 2001. Development of amino acids and organic acids in Norvegia, influence of milk treatment and adjunct Lactobacillus. Int. Dairy J. 11:399-411.

Suriyaphan, O., M. A. Drake, X. Q. Chen, and K. R. Cadwallader. 2001. Characteristic aroma components of British Farmhouse Cheddar cheese. J. Agric. Food Chem. 49:1382-1387.

Tungjaroenchai, W., C. H. White, W. E. Holmes, and M. A. Drake. 2004. Influence of adjunct cultures on volatile free fatty acids in reduced-fat Edam cheeses. J. Dairy Sci. 87:3224-3234.
Upreti, P., L. E. Metzger, and P. Bühlmann. 2004. Glass and polymeric membrane electrodes for the measurement of $\mathrm{pH}$ in milk and cheese. Talanta 63:139-148.

Urbach, G. 1993. Relations between cheese flavour and chemical composition. Int. Dairy J. 3:389-422.

Urbach, G. 1997. The flavour of milk and dairy products: II. Cheese: Contribution of volatile compounds. Int. Dairy J. 50:79-89.

US Dairy Export Council. 2012. Cheese: Getting to the next billion. Accessed May 22, 2017. http://blog.usdec.org/usdairyexporter/ cheese-getting-to-the-next-billion.

USDA. 2014. National Agricultural Statistics Service: Quick stats. Accessed Sep. 21, 2015. http://quickstats.nass.usda.gov/.

van den Berg, G., W. C. Meijer, E. M. Düsterhöft, and G. Smit. 2004. Gouda and related cheeses. Pages 103-140 in Cheese: Chemistry, Physics and Microbiology. 3rd ed. P. F. Fox, P. L. H. McSweeney, T. M. Cogan, and T. P. Guinee, ed. Elsevier, London, UK.

van den Dool, H., and P. Kratz. 1963. A generalization of the retention index system including linear programmed gas liquid partition chromatography. J. Chromatogr. 11:463-471.

Van Leuven, I., T. Van Caelenberg, and P. Dirinck. 2008. Aroma characterisation of Gouda-type cheeses. Int. Dairy J. 18:790-800.

Walstra, P., A. Noomen, and T. J. Geurts. 1993. Dutch-type varieties. Pages 39-82 in Cheese: Chemistry, Physics and Microbiology. 2nd ed. P. F. Fox, ed. Chapman and Hall, London, UK.

Welthagen, J. J., and B. C. Viljoen. 1998. Yeast profile in Gouda cheese during processing and ripening. Int. J. Food Microbiol. 41:185-194.

Whetstine, M. E. C., and M. A. Drake. 2007. The flavor and flavor stability of skim and whole milk powders. Pages 217-251 in Flavor of Dairy Products. K. R. Cadwallader, M. A. Drake, and R. J. McGorrin, ed. American Chemical Society, Washington, DC.

Wright, J. M., M. E. C. Whetstine, R. E. Miracle, and M. A. Drake. 2006. Characterization of a cabbage off-flavor in whey protein isolate. J. Food Sci. 71:86-90.

Yates, M. D., and M. A. Drake. 2007. Texture properties of Gouda cheese. J. Sens. Stud. 22:493-506.

Young, N. D., M. A. Drake, K. Lopetcharat, and M. R. McDaniel. 2004. Preference mapping of Cheddar cheese with varying maturity levels. J. Dairy Sci. 87:11-19.

Yvon, M., and L. Rijnen. 2001. Cheese flavour formation by amino acid catabolism. Int. Dairy J. 11:185-201.

Yvon, M., S. Thirouin, L. Rijnen, D. Fromentier, and J. C. Gripon. 1997. An aminotransferase from Lactococcus lactis initiates conversion of amino acids to cheese flavor compounds. Appl. Environ. Microbiol. 63:414-419.

Zehentbauer, G., and G. A. Reineccius. 2002. Determination of key aroma components of Cheddar cheese using dynamic headspace dilution assay. Flavour Fragrance J. 17:300-305.

Zerfiridis, G. K., A. Vafopoulou-Mastrogiannaki, and E. LitopoulouTzanetaki. 1984. Changes during ripening of commercial Gruyère cheese. J. Dairy Sci. 67:1397-1405. 